\title{
Chemical Hydrogen Storage Using Polyhedral Borane Anions and Aluminum-Ammonia-Borane Complexes
}

\author{
Final Report
}

September 29, 2010

\author{
M. Frederick Hawthorne (Primary Contact), Satish S. Jalisatgi, Alexander V. \\ Safronov, Han Beak Lee, Jianguo Wu \\ International Institute of Nano and Molecular Medicine \\ University of Missouri \\ Columbia, Missouri 65211 \\ Phone: (573) 882-7016; Fax: (573) 884-6900 \\ E-mail: hawthornem@health.missouri.edu
}

DOE Technology Development Manager: Grace Ordaz

Phone: (202) 586-8350; Fax: (202) 586-9811

E-mail: ordaz@ee.doe.gov

DOE Project Officer: Jim Alkire

Phone: (303) 275-4795

E-mail: jim.alkire@do.doe.gov

Contract Number: DE-FC36-05G015058

Project Start Date: September 2005

Project End Date: June 2010

\section{Executive Summary}

This project was part of the DOE Center of Excellence for chemical hydrogen storage led by the Los Alamos National Laboratory. The project was initiated at UCLA in 2005 and later moved to the University of Missouri in 2006 due to the transfer of the PI to Missouri. This program was divided into two phases; phase 1 was focused on development of transition metal-catalyzed hydrolysis of polyhedral borane anions, specifically nido- $\mathrm{B}_{11} \mathrm{H}_{14}{ }^{-}$, closo- $\mathrm{B}_{10} \mathrm{H}_{10}{ }^{2-}$ and closo- $\mathrm{B}_{12} \mathrm{H}_{12}{ }^{2-}$ to release hydrogen, while phase 2 was focused on the synthesis and dehydrogenation of aluminum amido-boranes. 
Phase 1. Hydrolysis of borohydride compounds offer the potential for significant hydrogen storage capacity, but most work to date has focused on one particular anion, $\mathrm{BH}_{4}^{-}$, which requires high $\mathrm{pH}$ for stability. Other borohydride compounds, in particular polyhedral borane anions offer comparable hydrogen storage capacity without requiring high $\mathrm{pH}$ media and their long term thermal and hydrolytic stability coupled with non-toxic nature make them a very attractive alternative to $\mathrm{NaBH}_{4}$.

The University of Missouri project provided the overall program focal point for the investigation of catalytic hydrolysis of polyhedral borane anions for hydrogen release. Due to their inherent stability, a transition metal catalyst was necessary for the hydrolysis of polyhedral borane anions. Transition metal ions such as cobalt, nickel, palladium and rhodium are known to form metal borides in the presence of reactive borane species. During the initial exploration, nickel boride $\left(\mathrm{Ni}_{2} \mathrm{~B}\right)$ and cobalt boride $\left(\mathrm{Co}_{2} \mathrm{~B}\right)$ were investigated for their catalytic activity in the hydrolysis of nido$\mathrm{KB}_{11} \mathrm{H}_{14}$, closo- $\mathrm{K}_{2} \mathrm{~B}_{10} \mathrm{H}_{10}$, and closo- $\mathrm{K}_{2} \mathrm{~B}_{12} \mathrm{H}_{12}$. Both $\mathrm{Ni}$ and $\mathrm{Co}$ borides were able to catalyze the hydrolysis of $\mathrm{KB}_{11} \mathrm{H}_{14}$, but not the other two closo- boranes. This was expected as nido- $\mathrm{KB}_{11} \mathrm{H}_{14}$ is an open nido- system and easily hydrolysable. We investigated other transition metal catalysts including ruthenium, palladium, platinum and iridium for the hydrolysis and found that only rhodium was able to catalyze all polyhedral borane anions investigated. The rate of hydrolysis follows first-order kinetics with respect to the concentration of the polyhedral borane anion and surface area of the rhodium catalyst. The rate of hydrolysis depends upon a) choice of polyhedral borane anion, c) concentration of polyhedral borane anion, d) surface area of the rhodium catalyst and e) temperature of the reaction. In all cases the yield of hydrogen was $100 \%$ which corresponds to $\sim 7 \mathrm{wt} \%$ of hydrogen (based on material wt\%).

We also investigated the mechanism of the hydrolysis reaction. Our preliminary observations suggest that a B-H bond is necessary for the hydrolysis of these polyhedral borane ions.

This project was down selected by the center for on-board storage applications due the cost prohibitive regenerative approach and limited hydrogen wt $\%$.

Key findings of the project

- Rhodium catalyst exhibited the highest catalytic activity among a number of transition metal catalysts investigated. $\mathrm{Co}_{2} \mathrm{~B}$ and $\mathrm{Ni}_{2} \mathrm{~B}$ were able to catalyse hydrolysis of nido- $\mathrm{KB}_{11} \mathrm{H}_{14}$ but not the other two closo- $\mathrm{K}_{2} \mathrm{~B}_{10} \mathrm{H}_{10}$ and closo$\mathrm{K}_{2} \mathrm{~B}_{12} \mathrm{H}_{12}$ borane ions.

- The rate of hydrogen release follows first-order kinetics with respect to the concentration of borane anions and surface area of the the Rh catalyst.

- The calculated activation energy values shows that the rate of hydrolysis decrease in order of nido- $\mathrm{KB}_{11} \mathrm{H}_{14}>$ closo- $\mathrm{K}_{2} \mathrm{~B}_{10} \mathrm{H}_{10}>\mathrm{K}_{2} \mathrm{~B}_{12} \mathrm{H}_{12}$.

- The presence of a $\mathrm{B}-\mathrm{H}$ bond is necessary for the hydrolysis of polyhedral boranes 
- These polyhedral borane ions are a viable alternative to sodium borohydride for portable power generation due to their non-toxic nature and their thermal and hydrolytic stability in the absence of catalysts.

Phase 2. In phase 2 of the program the Center has focused its efforts on developing amino boranes and metal ammonia-borane complexes (M-AB) as candidates for chemical hydrogen storage. The program at the University of Missouri was focused upon developing aluminum ammonia-boranes (Al-AB) specifically their synthesis and studies of their dehydrogenation. The ammonia borane molecule (AB) is a demonstrated source of chemically stored hydrogen (19.6 wt\%) which meets DOE performance parameters except for its regeneration from spent $A B$ and elemental hydrogen. The presence of an aluminum center bonded to multiple $A B$ residues might combine the efficiency of $A B$ dehydrogenation with an aluminum mediated hydrogenation process leading to reversibility. The Al-AB complexes have comparable hydrogen capacity with other M-AB and have potential to meet DOE's 2010 and 2015 targets for system wt\%.

For this study we evaluated $\left.\mathrm{Al}\left(\mathrm{NH}_{2} \mathrm{BH}\right)_{3}\right)_{3} \mathrm{LiAl}\left(\mathrm{NH}_{2} \mathrm{BH}_{3}\right)_{4}$ [ referred to as $\mathrm{Al}(\mathrm{AB})_{3}$ and $\mathrm{LiAl}(\mathrm{AB})_{4}$ respectively] and the ammonia adduct of $\mathrm{Al}(\mathrm{AB})_{3}$. The synthesis of $\mathrm{Al}(\mathrm{AB}) 3$ and $\mathrm{LiAl}(\mathrm{AB}) 4$ was accomplished using ammonia borane. A TGA-MS analysis of Al-AB complexes indicated that $\mathrm{Al}(\mathrm{AB})_{3}$ starts releasing hydrogen at around $60^{\circ} \mathrm{C}$ analogous to other MAB $(\mathrm{M}=\mathrm{Li}, \mathrm{Na})$ complexes. The $\mathrm{LiAl}(\mathrm{AB})_{4}$ complex starts releasing hydrogen at $80^{\circ} \mathrm{C}$ and peaks at around $170{ }^{\circ} \mathrm{C}$. The ammonia adduct $\mathrm{NH}_{3} \bullet \mathrm{Al}(\mathrm{AB})_{3}$ generates hydrogen at $100^{\circ} \mathrm{C}$ but also releases ammonia at $100^{\circ} \mathrm{C}$. A differential scanning calorimetric analysis on $\mathrm{Al}(\mathrm{AB})_{3}$ indicates that the hydrogen release process is exothermic and therefore will require an off-board regeneration process.

Hydrogen release experiments on $\mathrm{Al}(\mathrm{AB})_{3}$ and $\mathrm{LiAl}(\mathrm{AB})_{4}$ complexes were carried out at various temperatures by heating the complexes up to $190^{\circ} \mathrm{C}$ in the presence and absence of solvent or a catalyst. In the case of $\mathrm{Al}(\mathrm{AB})_{3}$ complex, approximately 4.1 moles of hydrogen is released at $190{ }^{\circ} \mathrm{C}$, which corresponds to about $6 \mathrm{wt} \%$ hydrogen based on material $w t \%$. The $\mathrm{LiAl}(\mathrm{AB})_{4}$ complex under similar experimental conditions released approximately 5.2 moles of hydrogen which corresponds to around $7 \mathrm{wt} \%$ hydrogen based on material wt\%. Addition of an ionic liquid catalyst increased the hydrogen release performance of these materials by $25-30 \%$ with virtually no induction period.

Key findings of the project

- Synthesized various $\mathrm{Al}-\mathrm{AB}$ complexes. These include $\mathrm{Al}(\mathrm{AB})_{3}, \mathrm{LiAl}(\mathrm{AB})_{4}$ and their ammonia adduct of $\mathrm{Al}(\mathrm{AB})_{3}$.

- $\mathrm{Al}(\mathrm{AB})_{3}$ complex releases hydrogen at $60{ }^{\circ} \mathrm{C}$ while the $\mathrm{LiAl}\left(\mathrm{NH}_{2} \mathrm{BH}_{3}\right)_{4}$ complex starts releasing hydrogen at $80^{\circ} \mathrm{C}$.

- The ammonia adduct of $\mathrm{Al}(\mathrm{AB})_{3}$ generates hydrogen at $100{ }^{\circ} \mathrm{C}$, but also releases a significant amount of ammonia. 
- Presence of an ionic liquid enhances hydrogen release perfomance of Al-AB complexes.

- Differential scanning calorimetric studies on $\mathrm{Al}(\mathrm{AB})_{3}$ indicate that the hydrogen release from this complex is exothermic and will require off-board regeneration.

This program involved active collaboration from other center partners in the form of analytical support, meetings and regular discussions. The hydrolysis project has resulted in one publication and number of presentations. The aluminum amidoborane project results will shortly be submitted for publication. 


\section{Phase I: Chemical Hydrogen Storage Using Polyhedral Borane Anion Salts.}

\section{Objective:}

- Develop heterogeneous catalysts for the controlled generation of hydrogen from the hydrolysis of salts of $\mathrm{B}_{12} \mathrm{H}_{12}{ }^{2-}, \mathrm{B}_{10} \mathrm{H}_{10}{ }^{2-}$ and $\mathrm{B}_{11} \mathrm{H}_{14}{ }^{-}$ions.

- Determine the kinetics and mechanism of these catalyzed borane anion hydrolysis reactions to provide design data for large-scale hydrogen generation devices.

\section{Technical Barriers}

This project addresses the following technical barriers from the 3.3.4 section of the Hydrogen, Fuel Cells and Infrastructure Technologies Program Multi-Year Research, Development and Demonstration Plan:
(A) System Weight and Volume
(B) System Cost
(C) Efficiency
(E) Charging/Discharging Rates

\section{Introduction -}

Hydrogen is considered to be a clean alternative to hydrocarbon-based fuels. Hydrogen coupled with the proton exchange membrane (PEM) fuel cell is an attractive power source capable of providing clean energy for transportation, and both portable and stationary power applications.[1] Hydrogen fuel can be derived from a variety of sources, including chemical hydrogen storage systems such as metal hydrides and borohydrides. Considerable efforts have been focused on hydrogen generation from the hydrolysis of light metal hydrides such as $\mathrm{NaBH}_{4}$, $\mathrm{NaH}, \mathrm{CaH}_{2}, \mathrm{MgH}_{2}$, $\mathrm{LiAlH}_{4}$, etc.[2] Among these metal hydrides, $\mathrm{NaBH}_{4}$ has attracted the most attention because of its relatively low cost, its hydrogen capacity of $>6 \mathrm{wt} \%$ (including water co-reactant), and because its hydrolysis can be catalytically initiated and controlled at ambient temperature. Even though the metal-catalyzed hydrolysis of $\mathrm{NaBH}_{4}$ is straightforward and the byproduct $\mathrm{NaB}(\mathrm{OH})_{4}$ is environmentally benign, [3] one of the drawbacks of $\mathrm{NaBH}_{4}$ is that the sodium borohydride storage solution must be kept at a high $\mathrm{pH}$. Even this does not completely prevent slow hydrolysis over time due to slow protolysis with water.

Polynuclear (or polyhedral) boranes with the general formula $\mathrm{B}_{n} \mathrm{H}_{n}{ }^{2-}$ where $\mathrm{n}=$ 6-12 have been extensively studied for the past 50 years and their chemistry is well established.[4] As shown in Figure 1, the $\mathrm{B}_{11} \mathrm{H}_{14}$ ion is an open-faced nido structure, $\mathrm{B}_{10} \mathrm{H}_{10}{ }^{2-}$ dianion is a bicapped square antiprism closo structure and $\mathrm{B}_{12} \mathrm{H}_{12}{ }^{2-}$ dianion has icosahedral closo geometry. Geometrically, polynuclear borane anions have trigonal faces. For example icosahedral closo- $\mathrm{B}_{12} \mathrm{H}_{12}{ }^{2-}$ consists of 12 boron atoms each bonded to 5 neighboring boron atoms within the icosahedron and to an external atom such as hydrogen. One or more $\mathrm{BH}$ vertices can be exchanged for 
isoelectronic $\mathrm{CH}^{+}$vertices giving rise to a variety of carborane structures. Diverse functionalization at the resulting $\mathrm{CH}$ vertices provides novel structures having unique applications in material science and biomedicine. [5]
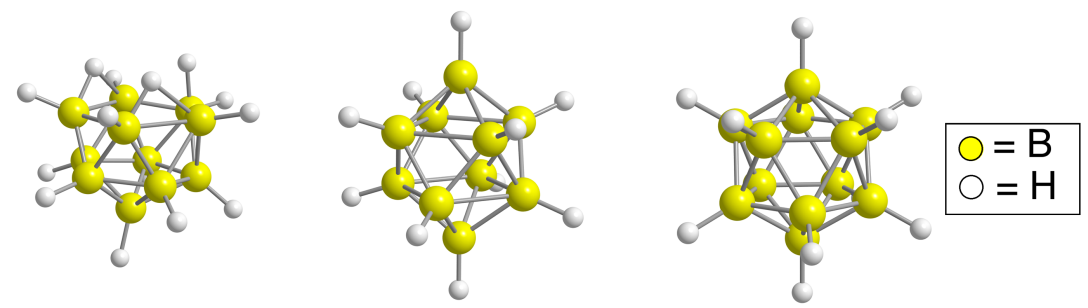

$$
\text { nido- }\left[\mathrm{B}_{11} \mathrm{H}_{14}\right]^{-} \text {closo- }\left[\mathrm{B}_{10} \mathrm{H}_{10}\right]^{2-} \text { closo- }\left[\mathrm{B}_{12} \mathrm{H}_{12}\right]^{2-}
$$

Figure 1. Polynuclear borane anions investigated in this study.

The polynuclear borane dianions closo- $\mathrm{B}_{10} \mathrm{H}_{10}{ }^{2-}$ and closo- $\mathrm{B}_{12} \mathrm{H}_{12}{ }^{2-}$ can be considered to be non-toxic and stable alternatives to $\mathrm{BH}_{4}{ }^{-}$as hydrogen storage materials. The hydrogen generating capacity of polynuclear borane anions investigated in this report is comparable to sodium borohydride and shown in Figure 2. They are thermally stable at least up to $500{ }^{\circ} \mathrm{C}$ in the solid state and are stable in aqueous solutions at elevated temperatures for an indefinite period of time. Major advantages of using polynuclear boranes for hydrogen storage are a) Hydrolytic stability: Salts of the polyborane anions are unreactive towards water in the absence of a catalyst, thus eliminating the need for stabilization additives and caustic solutions; b) Flexibility: Mixtures of polynuclear borane anions may be used as fuel "blends"; [6] and c) Non-toxicity: The $\mathrm{LD}_{50}$ value for $\mathrm{Na}_{2} \mathrm{~B}_{12} \mathrm{H}_{12}$ in mice is $1,200 \mathrm{mg} / \mathrm{kg}$ body weight. $[7,8]$

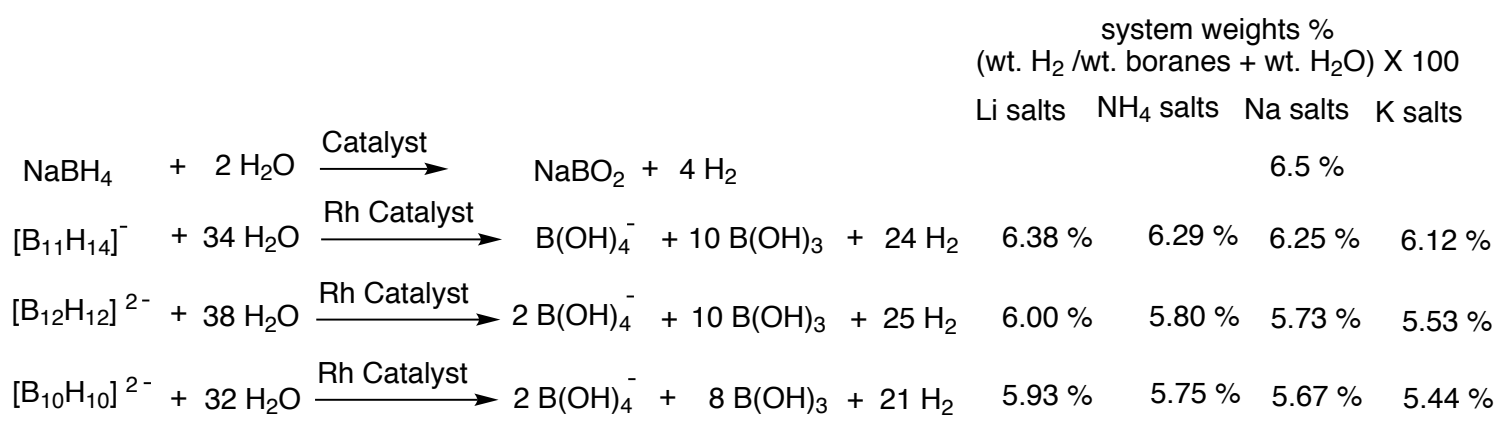

Figure 2. Hydrogen wt\% of the available borane anion systems including water coreactant.

\section{Materials and Methods}


The starting materials closo- $\left[\left(\mathrm{C}_{2} \mathrm{H}_{5}\right)_{3} \mathrm{NH}\right]_{2} \mathrm{~B}_{10} \mathrm{H}_{10}$ [9] and closo- $\left[\left(\mathrm{C}_{2} \mathrm{H}_{5}\right)_{3} \mathrm{NH}\right]_{2} \mathrm{~B}_{12} \mathrm{H}_{12}$ [10] were prepared according to published methods starting from commercially available decaborane. Potassium salts of these boranes were prepared by exchanging $\left(\mathrm{C}_{2} \mathrm{H}_{5}\right)_{3} \mathrm{NH}^{+}$ion to $\mathrm{K}^{+}$ion using DOWEX ${ }^{\mathrm{TM}} 50 \mathrm{~W}-\mathrm{X} 8$ cation exchange resin charged with $\mathrm{K}^{+}$ion. Borane anion derivatives closo- $\mathrm{Cs}_{2} \mathrm{~B}_{12}(\mathrm{OH})_{12},{ }^{\left[11^{]}\right.}$and closo$\mathrm{K}_{2} \mathrm{~B}_{10} \mathrm{Cl}_{10}$ [12] were synthesized using previously published procedures. Cobalt boride $\left(\mathrm{CO}_{2} \mathrm{~B}\right)$ and nickel boride $\left(\mathrm{Ni}_{2} \mathrm{~B}\right)$ were prepared in accordance to literature methods. [13]

The purity of all starting materials was established for the hydrolysis studies based on their ${ }^{1} \mathrm{H},{ }^{11} \mathrm{~B}$ and ${ }^{11} \mathrm{~B}\left\{{ }^{1} \mathrm{H}\right\}$ NMR and MS spectra. All ${ }^{11} \mathrm{~B}$ NMR spectra were recorded using a Bruker DRX-500 spectrometer at $160 \mathrm{MHz}$ and externally referenced to $\mathrm{BF}_{3}{ }^{\circ} \mathrm{Et}_{2} \mathrm{O}$; resonances upfield to the reference are designated as negative. Mass spectra were recorded on Applied Biosystems Mariner ESI-TOF spectrometer.

\subsection{Synthesis of nido-potassium undecaborate $\left(\mathrm{KB}_{11} \mathrm{H}_{14}\right)$}

The title compound was prepared by modifying the published method. [14] A mixture of decaborane $(3.0 \mathrm{~g}, 24.5 \mathrm{mmol})$ and potassium borohydride $(1.3 \mathrm{~g}, 24.2 \mathrm{mmol})$ was evacuated at $-30^{\circ} \mathrm{C}$ and backfilled with argon at least three times. To this mixture, $150 \mathrm{~mL}$ of anhydrous dioxane was added and the reaction mixture was heated at $85^{\circ} \mathrm{C}$ for $20 \mathrm{~h}$ under argon. The reaction mixture was chilled with an iced water bath and filtered to give a yellow precipitate. The collected yellow products were re-dissolved in hot glyme $(120 \mathrm{~mL})$ and filtered. The filtrate was concentrated to $60 \mathrm{~mL}$ and mixed with $200 \mathrm{~mL}$ of dioxane. The solution was kept at $4{ }^{\circ} \mathrm{C}$ in a refrigerator for 2 days and resulting crystals were separated by filtration to give 1.51 $\mathrm{g}(36 \%)$ of nido- $\mathrm{KB}_{11} \mathrm{H}_{14}$. The spectral data agreed with literature values. [14a]

\subsection{Synthesis of closo-dicesium dodecachlorododecaborate $\left(\mathrm{Cs}_{2} \mathrm{~B}_{12} \mathrm{Cl}_{12}\right)$}

To a solution of $\mathrm{K}_{2} \mathrm{~B}_{12} \mathrm{H}_{12}(1.00 \mathrm{~g}, 4.55 \mathrm{mmol})$ in $25 \mathrm{ml}$ of dry acetonitrile, $\mathrm{N}$ chlorosuccinimide $(9.11 \mathrm{~g}, 68.3 \mathrm{mmol})$ was added and the reaction mixture was heated at reflux for $48 \mathrm{~h}$. An additional amount of N-chlorosuccinimide $(3.04 \mathrm{~g}, 22.8$ $\mathrm{mmol}$ ) was added and the reaction mixture was refluxed for another $24 \mathrm{~h}$, after which an additional portion of $\mathrm{N}$-chlorosuccinimide $(2.00 \mathrm{~g}, 9 \mathrm{mmol})$ was added to the reaction mixture and heated for an additional $24 \mathrm{~h}$. The reaction mixture was evaporated to dryness, mixed with $20 \mathrm{~mL}$ water and filtered. Cesium sulfate $(1.56 \mathrm{~g}$, $4.55 \mathrm{mmol}$ ) was added and the resulting precipitate was filtered. The crude product was crystallized from water to give $2 \mathrm{~g}(80 \%)$ of $\mathrm{Cs}_{2} \mathrm{~B}_{12} \mathrm{Cl}_{12}$ as a colorless solid. ${ }^{11} \mathrm{~B}\left\{{ }^{1} \mathrm{H}\right\}$ NMR (DMSO- $\mathrm{d}_{6}, 160 \mathrm{MHz}$ ): $\delta-12.10$ (s). MS (ES') calculated for $\mathrm{B}_{12} \mathrm{Cl}_{12}{ }^{2-}$ $(M)^{2-}: 277.868$, Found: 277.389 . These values are in agreement with literature values. [15]

\subsection{Synthesis of mixture of closo-heptachlorodecaborate and closo- octachlorodecaborate, [(Me $\left.3 \mathrm{NH})_{2} \mathrm{~B}_{10} \mathrm{H}_{3} \mathrm{Cl}{ }_{7}\right]$ and $\left[\left(\mathrm{Me}_{3} \mathrm{NH}\right)_{2} \mathrm{~B}_{10} \mathrm{H}_{2} \mathrm{Cl}_{8}\right]$.}

To a solution of $\mathrm{K}_{2} \mathrm{~B}_{10} \mathrm{H}_{10}(0.100 \mathrm{~g}, 0.509 \mathrm{mmol})$ in $25 \mathrm{~mL}$ dry acetonilrile, $\mathrm{N}$ chlorosuccinimide $(0.545 \mathrm{~g}, 4.07 \mathrm{mmol})$ was added and the reaction mixture was heated at reflux temperature for $12 \mathrm{~h}$. The reaction mixture was then evaporated to 
dryness, dissolved in $20 \mathrm{~mL}$ double distilled water and filtered. Addition of trimethylamine hydrochloride $(0.146 \mathrm{~g}, 1.53 \mathrm{mmol})$ to the reaction mixture gave a white precipitate, which was filtered and crystallized from double distilled water to give $0.180 \mathrm{~g}$ of mixture of $\left[\left(\mathrm{Me}_{3} \mathrm{NH}\right)_{2} \mathrm{~B}_{10} \mathrm{H}_{3} \mathrm{Cl}_{7}\right]$ and $\left[\left(\mathrm{Me}_{3} \mathrm{NH}\right)_{2} \mathrm{~B}_{10} \mathrm{H}_{2} \mathrm{Cl}_{8}\right]$ as a white solid. MS (+ESI): Calculated for $\left[\left(\mathrm{Me}_{3} \mathrm{NH}\right)_{2} \mathrm{~B}_{10} \mathrm{H}_{3} \mathrm{Cl}_{7}\right]^{-} \mathrm{Me}_{3} \mathrm{NH}^{+}=538.14$, Found $=$ 539.21; Calculated for $\left[\left(\mathrm{Me}_{3} \mathrm{NH}\right)_{2} \mathrm{~B}_{10} \mathrm{H}_{3} \mathrm{Cl}_{8}\right]^{-} \mathrm{Me}_{3} \mathrm{NH}^{+}=574.10$, Found $=573.18$.

\subsection{Preparation of a heterogeneous rhodium metal catalyst}

A solution of sodium borohydride $(0.14 \mathrm{~g}, 3.80 \mathrm{mmol})$ in $15 \mathrm{~mL}$ of double distilled water was added dropwise to a solution of $\mathrm{RhCl}_{3} \cdot 3 \mathrm{H}_{2} \mathrm{O}(0.10 \mathrm{~g}, 0.38 \mathrm{mmol})$ in $5 \mathrm{~mL}$ of double distilled water in an ice bath. The reaction mixture was stirred for 10 minutes and the fine black precipitate formed was filtered and washed with water $(10 \times 15 \mathrm{~mL})$ until no evidence of boric acid was visible in washings by ${ }^{11} \mathrm{~B} N \mathrm{NM}$. The precipitate was further washed with ethanol $(5 \mathrm{~mL})$ and dried under vacuum at 100 ${ }^{\circ} \mathrm{C}$ for $12 \mathrm{~h}$ to give a fine black powder $(0.037 \mathrm{~g}, 95 \%)$. Anal. Found $=99.9 \% \mathrm{Rh}$; Particle Size:- $240 \mathrm{~nm}$.; Surface Area:- $55 \mathrm{~m}^{2} / \mathrm{g}$.

\subsection{Synthesis of mixed rhodium catalysts}

Three $\mathrm{Rh} / \mathrm{Co}$ mixed catalysts were synthesized by varying the ratio of $\mathrm{RhCl}_{3} \cdot 3 \mathrm{H}_{2} \mathrm{O}$ and $\mathrm{CoCl}_{2} \cdot 6 \mathrm{H}_{2} \mathrm{O}$ from $3: 1$ to $1: 1$ and $1: 3$, respectively. The mixtures were then reacted with an excess of $\mathrm{NaBH}_{4}$ solution in water to give the corresponding $\mathrm{Rh} / \mathrm{Co}$ mixed catalysts. The procedure was identical to the one described above for the preparation of a rhodium catalyst.

\subsection{Typical rhodium metal-catalyzed hydrolysis experiment}

A solution of borane anion salt in double distilled water $(10 \mathrm{~mL})$ was placed into a heavy-duty Schlenk tube equipped with a magnetic stirring bar and an adapter to connect to a mercury manometer. The solution was heated to $80^{\circ} \mathrm{C}$ in an oil bath equipped with a high precision temperature controller. After 20 minutes of stirring, the Rh catalyst was added to the reaction mixture, and the system was sealed for pressure monitoring. The production of hydrogen vs. time was measured using a mercury manometer. On completion of the reaction, the pressure was released and the reaction mixture was analyzed by ${ }^{11} \mathrm{~B} N M R$. The NMR spectrum showed a single peak at $\delta 16.7 \mathrm{ppm}$ corresponding to potassium metaborate, indicating that the hydrolysis reaction was complete. Initial rate data was taken from the slope of the $\mathrm{PH}_{2}$ vs. time plot and converted to the initial $\mathrm{d}\left[\mathrm{H}_{2}\right] / \mathrm{dt}$ in the differential form of the pseudo first-order rate expression.

\section{Results and Discussion}

\subsection{Nature of the Catalyst}

In this study a number of transition metal catalysts were investigated. Transition metals such as $\mathrm{Co}$ and $\mathrm{Ni}$ form borides in the presence of borane. [13] Consequently, ionic transition metal catalysts would most likely be converted to their respective borides at the outset of the hydrolysis reaction. This possibility can be eliminated by employing transition metal borides as exploratory catalysts that are 
inert to further modification by borane species present in the reaction mixture. For purposes of initial exploration, nickel boride $\left(\mathrm{Ni}_{2} \mathrm{~B}\right)$ and cobalt boride $\left(\mathrm{Co}_{2} \mathrm{~B}\right)$ were examined for their catalytic activity in the hydrolysis of closo- $\mathrm{K}_{2} \mathrm{~B}_{10} \mathrm{H}_{10}$, closo$\mathrm{K}_{2} \mathrm{~B}_{12} \mathrm{H}_{12}$ and nido- $\mathrm{KB}_{11} \mathrm{H}_{14}$. These catalysts were prepared by a modified Schlesinger procedure [13] which involved the addition of an excess of aqueous $\mathrm{NaBH}_{4}$ solution to an aqueous solution of $\mathrm{NiCl}_{2}$ and $\mathrm{CoCl}_{2}$, respectively. The product was isolated by filtration and washed with water to remove any excess borohydride present. Both $\mathrm{Ni}$ and Co borides were able to catalyze the hydrolysis of $\mathrm{KB}_{11} \mathrm{H}_{14}$, which is a open nido cage system and easily hydrolyzed. However these $\mathrm{Ni}_{2} \mathrm{~B}$ and $\mathrm{Co}_{2} \mathrm{~B}$ were unable to catalyze the hydrolysis of closo- $\mathrm{K}_{2} \mathrm{~B}_{10} \mathrm{H}_{10}$ and closo$\mathrm{K}_{2} \mathrm{~B}_{12} \mathrm{H}_{12}$. In order to find a catalyst that will control the hydrolysis of all three borane clusters, we investigated late transition metals including palladium, iridium and platinum in the form of sponges; ruthenium and rhodium metal catalysts prepared by reacting $\mathrm{RuCl}_{3}$ and $\mathrm{RhCl}_{3}$ with excess of $\mathrm{NaBH}_{4}$ in water. From all metals tested only rhodium metal was able to catalyze the hydrolysis of all the three borane anions investigated in this study.

Rhodium black was prepared in a fashion similar to that used for cobalt boride and nickel boride, by reacting $\mathrm{RhCl}_{3}$ with an excess of $\mathrm{NaBH}_{4}$ in water. (See Materials and Methods section for details). The elemental analysis of this rhodium catalyst showed it to be rhodium metal rather than rhodium boride. Its measured BET surface area was $\sim 55 \mathrm{~m}^{2} / \mathrm{g}$ and the majority of the catalyst was monodisperse with a particle size of $240 \mathrm{~nm}$ as determined by dynamic light scattering. However, the presence of a few larger particles in the sample averages the particle size to approximately $1 \mu \mathrm{m}$.

We also briefly investigated mixed catalyst systems of cobalt and rhodium, synthesized by mixing various amounts of $\mathrm{CoCl}_{2}$ and $\mathrm{RhCl}_{3}$ and reacting these mixtures with an excess of aqueous $\mathrm{NaBH}_{4}$. The catalytic activity of these mixed catalyst systems corresponded to the percentage of rhodium present in the catalyst.

\subsection{Hydrogen generation}

In a typical hydrogen release experiment, the hydrolysis was performed at $80^{\circ} \mathrm{C}$ by adding the Rh catalyst to an aqueous solution of the polynuclear borane anion salt. Figure 3 shows equivalents of hydrogen released as a function of time from the hydrolysis of closo- $\mathrm{K}_{2} \mathrm{~B}_{10} \mathrm{H}_{10}(0.013 \mathrm{M})$ and closo $-\mathrm{K}_{2} \mathrm{~B}_{12} \mathrm{H}_{12}(0.013 \mathrm{M})$ in the presence of a Rh metal catalyst $\left(0.077 \mathrm{~m}^{2}\right.$ effective surface area) at $80^{\circ} \mathrm{C}$. The total hydrogen yield obtained from this reaction was $>95 \%$ of the theoretically expected value (figure 2). The completion of the hydrolysis reaction was confirmed by taking the ${ }^{11} \mathrm{~B}$ NMR of the reaction mixture and observing the presence of the potassium metaborate peak at $\delta 16.7 \mathrm{ppm}$, and the absence of peaks corresponding to the borane anions. As expected, closo- $\mathrm{K}_{2} \mathrm{~B}_{10} \mathrm{H}_{10}$ releases hydrogen at a faster rate than the more stable closo- $\mathrm{K}_{2} \mathrm{~B}_{12} \mathrm{H}_{12}$. 


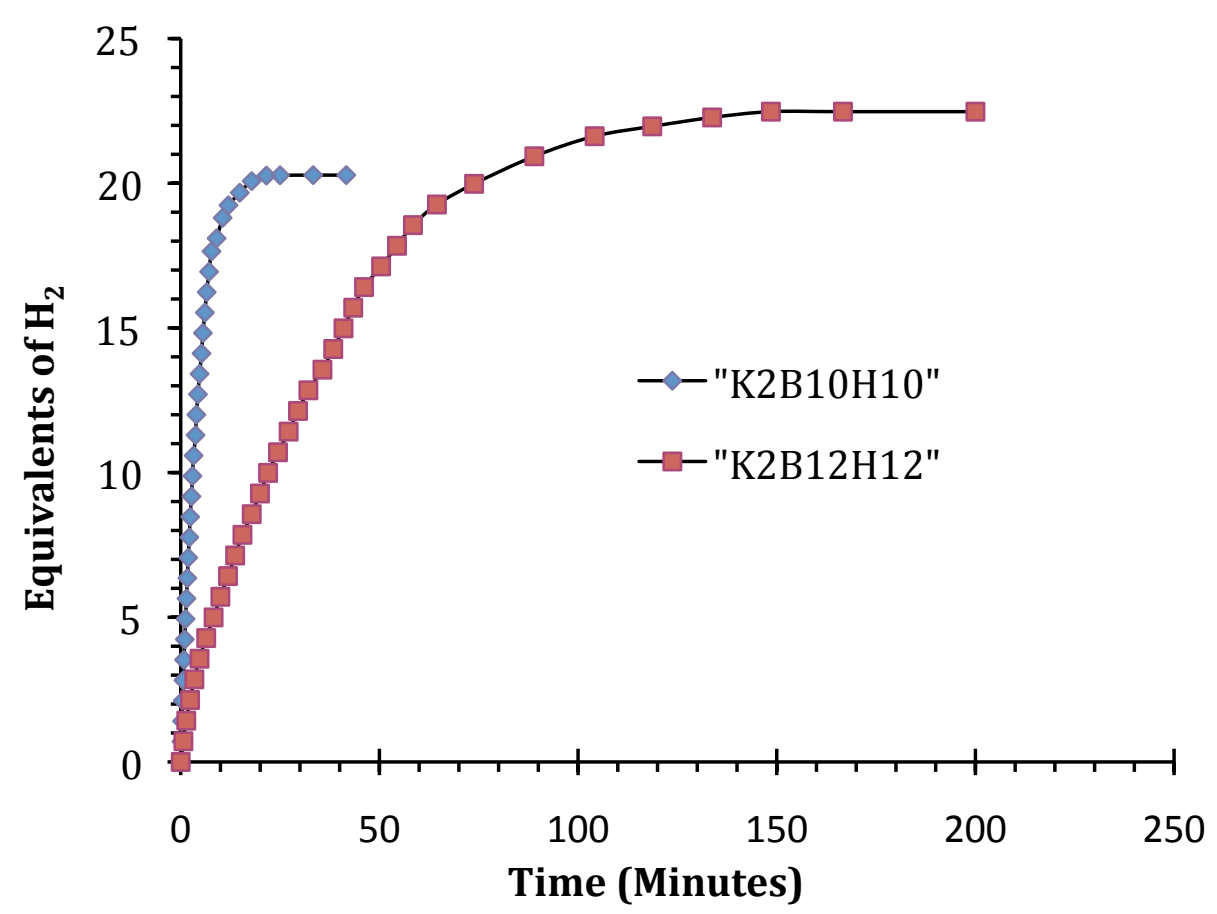

Figure 3. Equivalents of hydrogen generated from the rhodium catalyzed hydrolysis of borane anions, closo- $K_{2} B_{10} H_{10}(0.013 \mathrm{M})$, closo- $K_{2} B_{12} H_{12}(0.013 \mathrm{M})$, with $0.001 \mathrm{M}$ Rh metal catalyst (1.4 mg, $\sim 0.077 \mathrm{~m}^{2}$ surface area) at $80^{\circ} \mathrm{C}$.

\subsection{Hydrogen generation kinetics}

Polynuclear borane anions are kinetically very stable in aqueous solution even at elevated temperatures. In order to hydrolyze the borane anions employed in this study, a transition metal catalyst was required. For this study a number of salts of polynuclear borane anions such as $\mathrm{Na}, \mathrm{K}$ and $\mathrm{NH}_{4}$ were investigated. The choice of cations did not show any appreciable effect on the rate of hydrogen release.

However, for consistency the hydrolysis of potassium salts of the nido- $\mathrm{B}_{11} \mathrm{H}_{14}{ }^{-}$, closo$\mathrm{B}_{10} \mathrm{H}_{10}{ }^{2-}$ and closo- $\mathrm{B}_{12} \mathrm{H}_{12}{ }^{2-}$ anions are presented in this study. In each case the rate of hydrogen release depends upon the choice of borane anion, the choice of metal catalyst, the concentration of borane anion, and the effective surface area of heterogeneous catalyst. The rate of hydrolysis of borane clusters can be expressed by the following differential equation 1 where the concentration of borane anions and the surface area of the metal catalyst are dominant factors.

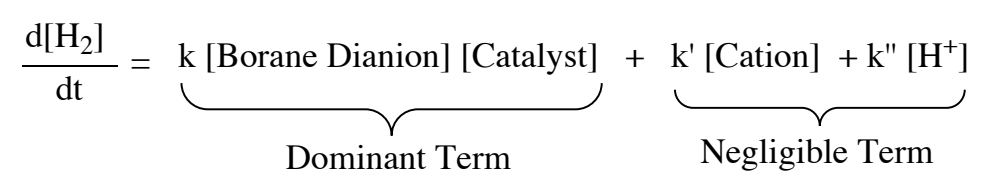


To effectively observe the kinetic expression of the rate of hydrolysis, the initial rate of reaction was fitted to the equation 1 using the initial concentrations of the reactants.

\subsection{Effect of borane anion concentration on the rate of hydrogen release}

To study the effect of borane anion concentration, the rhodium metal-catalyzed hydrolysis reaction was performed in water with $0.013,0.026,0.039,0.050$ and $0.075 \mathrm{M}$ initial concentrations of closo- $\mathrm{K}_{2} \mathrm{~B}_{10} \mathrm{H}_{10}$, closo- $\mathrm{K}_{2} \mathrm{~B}_{12} \mathrm{H}_{12}$ and nido- $\mathrm{KB}_{11} \mathrm{H}_{14}$. Appropriate solutions were made by adding a specific amount of the borane to 10 $\mathrm{mL}$ of water. The rate of hydrogen generation versus the initial concentration of borane anions is shown in Figure 4. It clearly indicates that the rate of hydrolysis increases with the increase in borane concentration. As expected, the closo- $\mathrm{B}_{12} \mathrm{H}_{12}{ }^{2-}$ anion hydrolyses slower than nido- $\mathrm{B}_{11} \mathrm{H}_{14}{ }^{-}$and closo- $\mathrm{B}_{10} \mathrm{H}_{10}{ }^{2-}$ since it is more stable than the other two borane anions. In the case of nido- $\mathrm{KB}_{11} \mathrm{H}_{14}$, the open nido structure facilitates a more rapid hydrolysis rate.

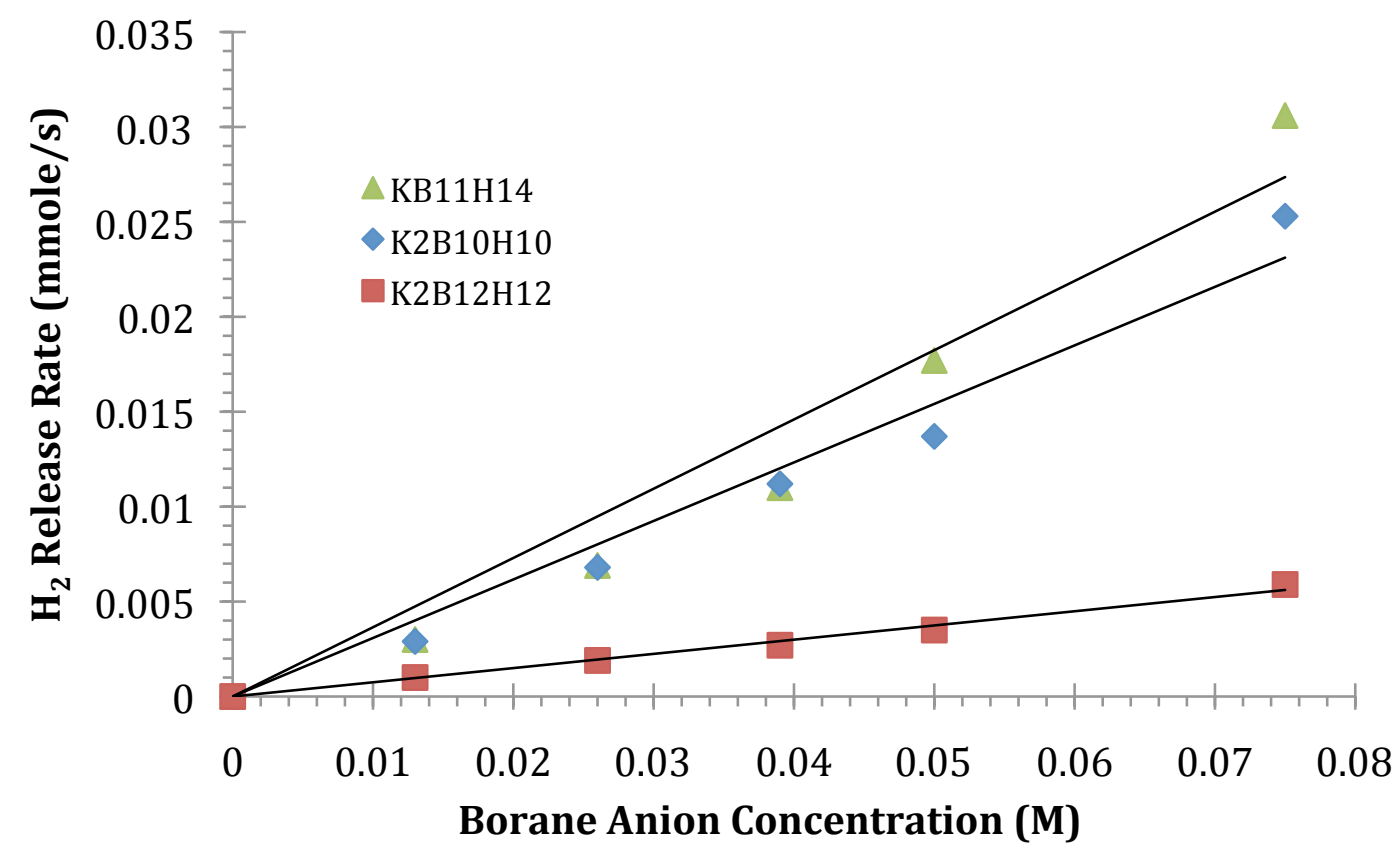

Figure 4. Effect of initial borane anion concentration on the $R h$ catalyzed hydrolysis of closo- $K_{2} B_{10} H_{10}$, closo- $K_{2} B_{12} H_{12}$ and nido- $K B_{11} H_{14}$. Data shown for $5 \mathrm{~mol} \%, R h$ catalyst (0.038 $\mathrm{m}^{2}$ to $0.46 \mathrm{~m}^{2}$ effective surface area) at $80{ }^{\circ} \mathrm{C}$.

\subsection{Effect of catalyst surface area on the rate of hydrogen production}

Figure 5 shows the hydrogen release rate measured using the prepared Rh metal catalyst and an $0.013 \mathrm{M}$ aqueous solution of borane anions at $80^{\circ} \mathrm{C}$. To investigate the effect of catalyst concentration on the rate of hydrogen release, various concentrations of Rh metal catalysts were employed (from $0.0 .038 \mathrm{~m}^{2}$ to $0.46 \mathrm{~m}^{2}$ ). The hydrogen release rate increased with an increase in the exposed catalyst 
surface, and followed a first-order dependence. This is expected since the rate of hydrolysis occurs at the catalyst surface. It is reasonable to postulate that increasing the surface area of the Rh metal catalyst by reducing the particle size will increase the rate of the reaction at lower catalyst concentration. Similarly, attaching nano-size $(<100 \mathrm{~nm})$ catalyst particles to a suitable surface will facilitate hydrogen release with reduced quantities of catalyst.

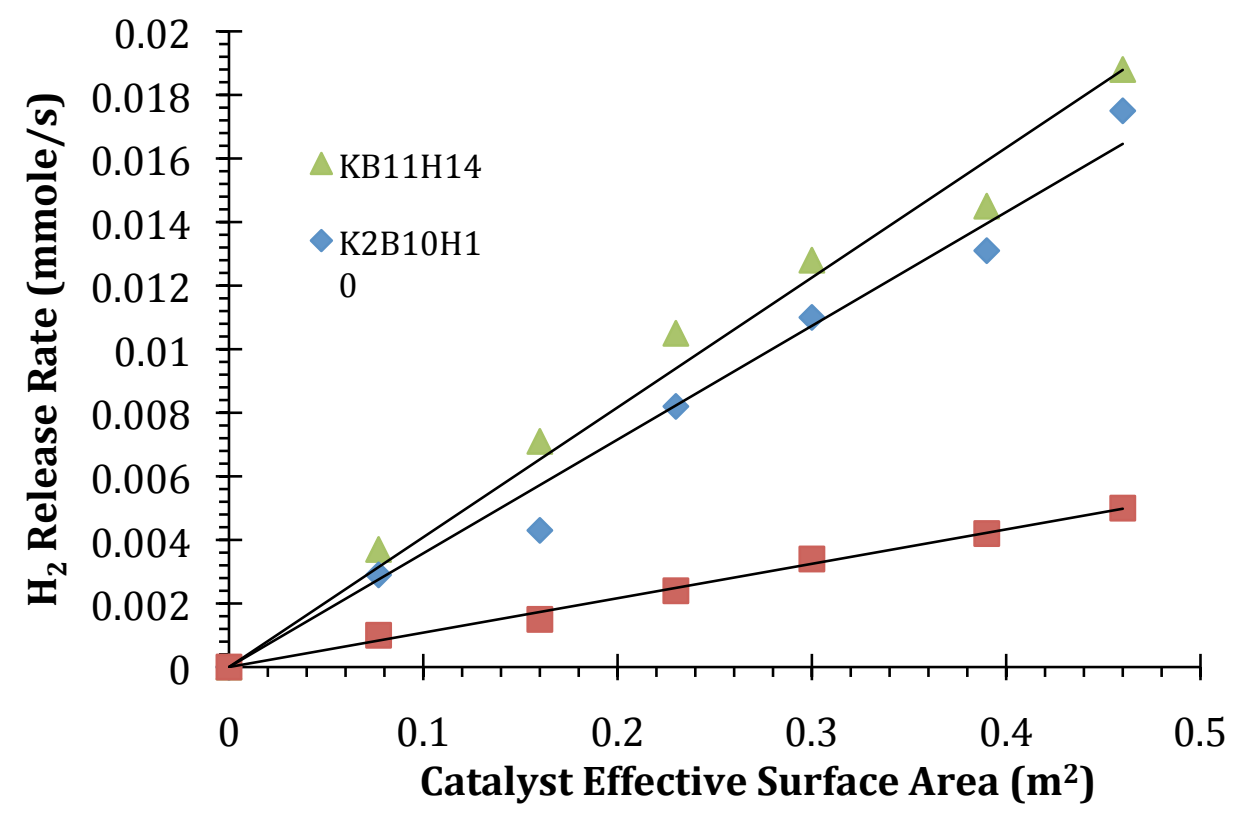

Figure 5. Effect of Rh catalyst surface area on the hydrolysis of nido-KB ${ }_{11} H_{14}$, closo- $K_{2} B_{10} H_{10}$ and closo- $K_{2} B_{12} H_{12}$. Data shown for $0.013 \mathrm{M}$ initial borane anion concentration at $80^{\circ} \mathrm{C}$.

\subsection{Activation Parameters of the Polynuclear Borane Anion Hydrolysis Reactions.}

The enthalpy $(\Delta \mathrm{H})$ and entropy of activation $(\Delta S)$ of the polynuclear borane hydrolysis reactions were determined using the Eyring equation and kinetic data measured at three different temperatures $\left(60,70\right.$ and $\left.80^{\circ} \mathrm{C}\right)$. The Erying plot of $\ln (k / T)$ vs. $1 / T$ for the various borane anions is shown in Figure 5 . The calculated activation enthalpies for nido- $\mathrm{KB}_{11} \mathrm{H}_{14}$, closo- $\mathrm{K}_{2} \mathrm{~B}_{10} \mathrm{H}_{10}$ and closo- $\mathrm{K}_{2} \mathrm{~B}_{12} \mathrm{H}_{12}$ were found to be 56,66 and $88 \mathrm{~kJ}^{-\mathrm{mol}^{-1}}$, and activation entropies to be $-189,-163$ and $108 \mathrm{~J} \cdot \mathrm{mol}^{-1} \cdot \mathrm{K}^{-1}$ respectively. These values are similar to the activation parameter values found for metal-catalyzed hydrolysis of $\mathrm{NaBH}_{4}$, [16] which suggests initial $\mathrm{B}-\mathrm{H}$ bond activation in polynuclear borane hydrolysis. Also, these values support the hypothesis that since closo- $\mathrm{B}_{12} \mathrm{H}_{12}{ }^{2-}$ is the most stable among the borane anions investigated, it hydrolyzes at a slower rate than closo- $\mathrm{B}_{10} \mathrm{H}_{10}{ }^{2-}$ and nido $-\mathrm{B}_{11} \mathrm{H}_{14}{ }^{-}$ anions. 


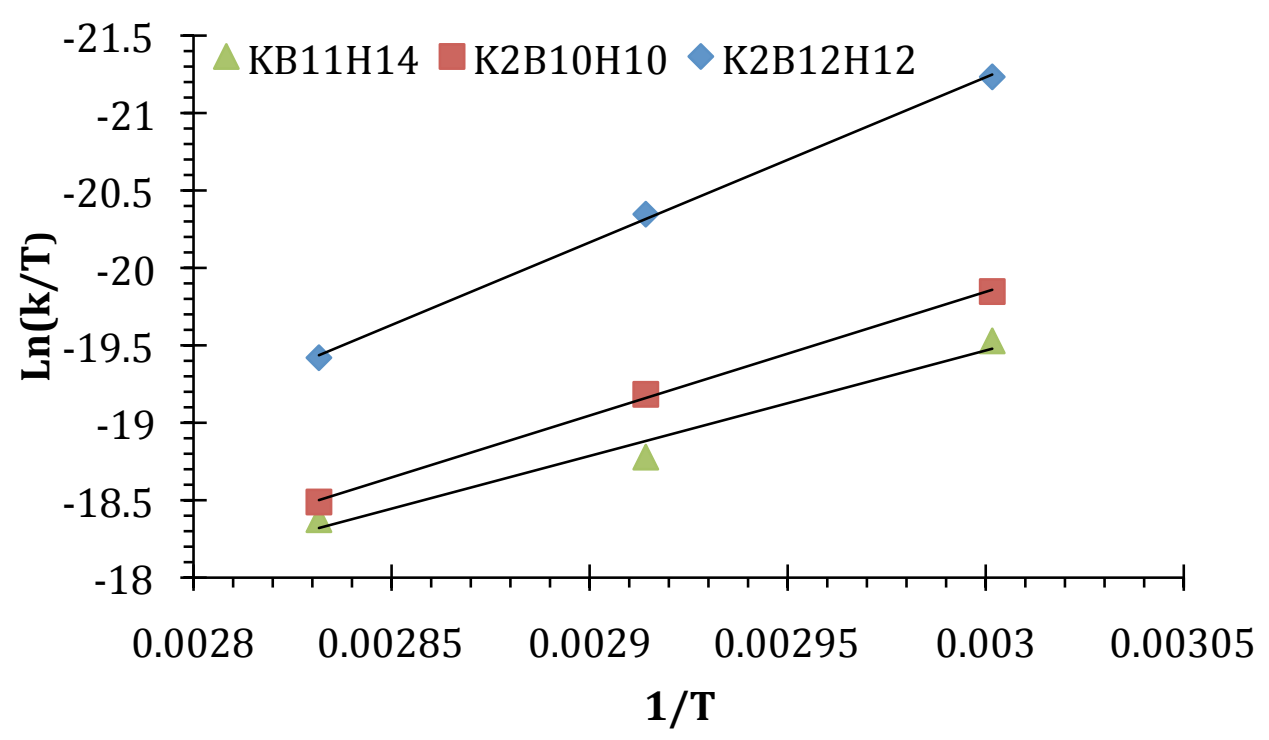

Figure 6. Eyring plot for $R h$ catalysed hydrolysis of nido- $K B_{11} H_{14}$, closo- $K_{2} B_{10} H_{10}$ and closo- $K_{2} B_{12} H_{12}$ (borane anion concentration: $0.013 \mathrm{M}$; Rh catalyst: $1 \mathrm{mg}(0.038$ $m^{2}$ effective surface area).

\subsection{Mechanism of hydrolysis reaction}

To understand the probable mechanism of the borane hydrolysis reaction, the catalyzed hydrolysis of various derivatives of closo- $\mathrm{B}_{10} \mathrm{H}_{10}{ }^{2-}$ and closo- $\mathrm{B}_{12} \mathrm{H}_{12}{ }^{2-}$ such as closo- $\mathrm{K}_{2} \mathrm{~B}_{10} \mathrm{Cl}_{10}$, closo- $\mathrm{K}_{2} \mathrm{~B}_{12} \mathrm{Cl}_{12}$, closo- $\mathrm{Cs}_{2} \mathrm{~B}_{12}(\mathrm{OH})_{12}$ and closo- $\mathrm{K}_{2} \mathrm{~B}_{10} \mathrm{Cl}_{8} \mathrm{H}_{2}$ (as a mixture of isomers) was attempted. Closo- $\mathrm{Cs}_{2} \mathrm{~B}_{12}(\mathrm{OH})_{12}$ was prepared by following literature method, [11] by reacting closo- $\mathrm{Cs}_{2} \mathrm{~B}_{12} \mathrm{H}_{12}$ with hydrogen peroxide at elevated temperature. Closo- $\mathrm{Cs}_{2} \mathrm{~B}_{10} \mathrm{Cl}_{10}$ was synthesized according to literature methods [12] by reacting $\left(\mathrm{NH}_{4}\right)_{2} \mathrm{~B}_{10} \mathrm{H}_{10}$ with chlorine gas and ion exchanging the resulting $\left(\mathrm{NH}_{4}\right)_{2} \mathrm{~B}_{10} \mathrm{Cl}_{10}$ with CsCl. Closo- $\mathrm{B}_{12} \mathrm{Cl}_{12}{ }^{2-}$ and closo- $\mathrm{B}_{12} \mathrm{Cl}_{10} \mathrm{H}_{2}{ }^{2-}$ (mixture of isomers) were prepared by chlorinating closo- $\mathrm{K}_{2} \mathrm{~B}_{12} \mathrm{H}_{12}$ with varying amount of $\mathrm{N}$ chlorosuccinimide in acetonitrile at reflux temperature. Conventionally these chlorinated boranes are prepared using elemental chlorine. [12, 15] We chose a milder chlorinating agent $\mathrm{N}$-chlorosuccinimide to give the corresponding chlorinated boranes in excellent yields. These salts were subjected to the same hydrolysis conditions as the parent borane anions. Among these derivatives, only the mixture of closo- $\mathrm{B}_{10} \mathrm{Cl}_{7} \mathrm{H}_{3}{ }^{2-}$ and closo- $\mathrm{B}_{10} \mathrm{Cl}_{8} \mathrm{H}_{2}{ }^{2-}$ underwent hydrolysis. This suggests that the presence of a $\mathrm{B}-\mathrm{H}$ bond is required to initiate the hydrolysis reaction. The Rh metalassisted polyhedral borane hydrolysis may begin with the oxidative addition of $\mathrm{Rh}$ to a BH bond (Rh-H-B) followed by the formation of an H-Rh-B bond. Subsequent hydrolysis takes place at a higher rate, releasing hydrogen and forming borates as byproduct. 


\section{Conclusion}

Polynuclear borane anions $\mathrm{B}_{11} \mathrm{H}_{14}{ }^{-}, \mathrm{B}_{10} \mathrm{H}_{10}{ }^{2-}$ and $\mathrm{B}_{12} \mathrm{H}_{12}{ }^{2-}$ are viable candidates for chemical hydrogen storage. They are very stable, non-toxic, environmentally harmless, non-flammable materials and offer high storage capacity $(>6.5 \%$ including co-reactant water) at an easily accessible metal-catalyzed hydrolysis temperature. A rhodium metal mediated hydrolysis of polynuclear borane anions releases more than $95 \%$ of hydrogen and forms non-toxic borates as by-products. The hydrogen release rates follow first-order kinetics with respect to the concentration of borane anions and surface area of the Rh catalyst. Overall, Rh black exhibited the highest catalytic activity among a number of transition metal catalysts investigated. $\mathrm{Co}_{2} \mathrm{~B}$ and $\mathrm{Ni}_{2} \mathrm{~B}$ were able to hydrolyze nido- $\mathrm{B}_{11} \mathrm{H}_{14}{ }^{-}$but were ineffective in hydrolyzing closo- $\mathrm{B}_{10} \mathrm{H}_{10}{ }^{2-}$ and closo- $\mathrm{B}_{12} \mathrm{H}_{12}{ }^{2-}$ dianions. The calculated activation energy values show that the rate of hydrogen release increases in order of nido- $\mathrm{B}_{11} \mathrm{H}_{14}{ }^{-}>$closo- $\mathrm{B}_{10} \mathrm{H}_{10}{ }^{2-}>$ closo$\mathrm{B}_{12} \mathrm{H}_{12}{ }^{2-}$ anions. These borane anions can be considered a safer and non-toxic alternative to unstable $\mathrm{NaBH}_{4}$ for portable long-term (years) hydrogen storage needs.

\subsection{Key Results}

- Determined an active Rh metal catalyst for the hydrolysis of polyhedral borane anion salts. The hydrogen release rate meets DOE 2010 targets.

- The rate of hydrolysis is first-order with respect to the concentration of borane anion salts and surface area of Rh metal catalyst.

- The presence of B-H bond is necessary for the hydrolysis of the borane anions. 


\section{Phase II: Chemical Hydrogen Storage Using Aluminum Ammonia Borane Complexes.}

\section{Objective:}

Investigate aluminum ammonia-borane complexes ( $\mathrm{Al}-\mathrm{AB}$ ) namely $\mathrm{Al}\left(\mathrm{NH}_{2} \mathrm{BH}_{3}\right)_{3}$ and $\mathrm{LiAl}\left(\mathrm{NH}_{2} \mathrm{BH}_{3}\right)_{4}$, and related species as hydrogen storage materials.

- Synthesize $\mathrm{Al}\left(\mathrm{NH}_{2} \mathrm{BH}_{3}\right)_{3}, \mathrm{H}_{3} \mathrm{~N} \cdot \mathrm{Al}\left(\mathrm{NH}_{2} \mathrm{BH}_{3}\right)_{3}$, $\mathrm{LiAl}\left(\mathrm{NH}_{2} \mathrm{BH}_{3}\right)_{4}$ and related species.

- Investigate hydrogen release performance of Al-AB complexes by thermal dehydrogenation process.

\section{Introduction}

The ammonia borane molecule $(A B)$ is a demonstrated source of chemically stored hydrogen and has the material capacity of 20 wt \% hydrogen. [17 ] It can meet DOE performance parameters except for its regeneration from spent $A B$ materials. There has been considerable interest in metal amido-borane complexes [ $M-A B$; $M$ $=\mathrm{Li}, \mathrm{Na}$ and $\mathrm{Ca}$ ] as hydrogen storage materials due to their facile hydrogen release properties at lower temperatures. The purity of hydrogen released is also higher compared to AB. [18] Our efforts were focused upon the synthesis and evaluation of aluminum amido-borane complexes as hydrogen storage materials. The presence of an aluminum center bonded to multiple $A B$ residues might combine the efficiency of $A B$ dehydrogenation with an aluminum mediated hydrogenation process leading to reversibility. The Al-AB complexes have comparable hydrogen capacity with other M-AB and have potential to meet DOE's 2010 and 2015 targets for system wt\% (figure 1). For this study we evaluated $\mathrm{Al}\left(\mathrm{NH}_{2} \mathrm{BH}_{3}\right)_{3}$, $\mathrm{LiAl}\left(\mathrm{NH}_{2} \mathrm{BH}_{3}\right)_{4}$ [ referred to as $\mathrm{Al}(\mathrm{AB})_{3}$ and $\mathrm{LiAl}(\mathrm{AB})_{4}$ respectively] and ammonia adduct of $\mathrm{Al}(\mathrm{AB})_{3}$.

$$
\begin{aligned}
& n \mathrm{Al}\left(\mathrm{NH}_{2} \mathrm{BH}_{3}\right)_{3}(\mathrm{~s}) \longrightarrow\left[\mathrm{Al}(\mathrm{NBH})_{3}\right]_{n}(\mathrm{~s})+6 n \mathrm{H}_{2}(\mathrm{~g})(10.3 \text { wt.\% Hydrogen }) \\
& n \mathrm{LiAl}\left(\mathrm{NH}_{2} \mathrm{BH}_{3}\right)_{4}(\mathrm{~s}) \longrightarrow\left[\mathrm{LiAl}(\mathrm{NBH})_{4}\right]_{n}(\mathrm{~s})+8 n \mathrm{H}_{2} \quad(\mathrm{~g})(10.4 \text { wt.\% Hydrogen })
\end{aligned}
$$

\subsection{Synthesis and characterization of Al-AB complexes}

All ${ }^{11} \mathrm{~B}$ and ${ }^{27} \mathrm{Al}$ NMR spectra were recorded using a Bruker DRX-500 spectrometer at $160 \mathrm{MHz}$ and $130 \mathrm{MHz}$ respectively. ${ }^{11} \mathrm{~B}$ NMR spectra were externally referenced to $\mathrm{BF}_{3} \cdot \mathrm{Et}_{2} \mathrm{O}$ and ${ }^{27} \mathrm{Al}$ NMR spectra are reported relative to $\mathrm{Al}\left(\mathrm{H}_{2} \mathrm{O}\right)_{6}{ }^{3+}$. IR spectra were recorded on a Nicolet NEXUS 470 FT-IR spectrometer.

$\mathrm{Al}(\mathrm{AB})_{3}$ : $\mathrm{A}$ number of routes were investigated for the preparation of $\mathrm{Al}(\mathrm{AB})_{3}$ including reaction of $\mathrm{AlH}_{3}$ with $\mathrm{AB}$ as well as reaction of trialkyl aluminum with $A B$. Of 
these routes, the reaction of $\mathrm{M}\left(\mathrm{NH}_{2} \mathrm{BH}_{3}\right)$ where $\mathrm{M}=\mathrm{Li}$, Na or $\mathrm{K}$ with $\mathrm{AlCl}_{3}$ gave the desired $\mathrm{Al}\left(\mathrm{NH}_{2} \mathrm{BH}_{3}\right)_{3}$ complex. The $\mathrm{M}\left(\mathrm{NH}_{2} \mathrm{BH}_{3}\right)$ were prepared from the reaction of $\mathrm{NH}_{3} \mathrm{BH}_{3}$ with corresponding metal hydrides. The reaction of $\mathrm{Li}\left(\mathrm{NH}_{2} \mathrm{BH}_{3}\right)$ with $\mathrm{AlCl}_{3}$ at low temperature gives $\mathrm{Al}\left(\mathrm{NH}_{2} \mathrm{BH}_{3}\right)_{3}$ in good yield, but the isolation of the pure product was not convenient due to the presence of $\mathrm{LiCl}$ in the mixture. Alternatively, the reaction of $\mathrm{Na}\left(\mathrm{NH}_{2} \mathrm{BH}_{3}\right)$ with $\mathrm{AlCl}$ proceeded well to give $\mathrm{Al}-\mathrm{AB}$ in $89 \%$ yield. The purity of the material was confirmed by ${ }^{11} \mathrm{~B}$ and ${ }^{27} \mathrm{AI}$ NMR and IR spectroscopy (figure 7) .

$$
\begin{aligned}
& 3 \mathrm{M}\left(\mathrm{NH}_{2} \mathrm{BH}_{3}\right)+\mathrm{AlCl}_{3} \rightarrow \mathrm{Al}\left(\mathrm{NH}_{2} \mathrm{BH}_{3}\right)_{3}+3 \mathrm{MCl} \\
& \mathrm{M}=\mathrm{Li}, \mathrm{Na} \text { or } \mathrm{K}
\end{aligned}
$$

$\mathrm{LiAl}\left(\mathrm{NH}_{2} \mathrm{BH}_{3}\right)_{4}$ : The synthesis of $\mathrm{LiAl}(\mathrm{AB})_{4}$ was achieved by reacting $\mathrm{LiAlH}_{4}$ with $\mathrm{AB}$ at room temperature for $24 \mathrm{~h}$. The product was characterized by ${ }^{11} \mathrm{~B}$ and ${ }^{27} \mathrm{Al}$ NMR spectra and IR spectroscopy.

$$
\mathrm{LiAlH}_{4}+4 \mathrm{NH}_{3} \mathrm{BH}_{3} \rightarrow \mathrm{LiAl}\left(\mathrm{NH}_{2} \mathrm{BH}_{3}\right)_{4}+2 \mathrm{H}_{2}
$$

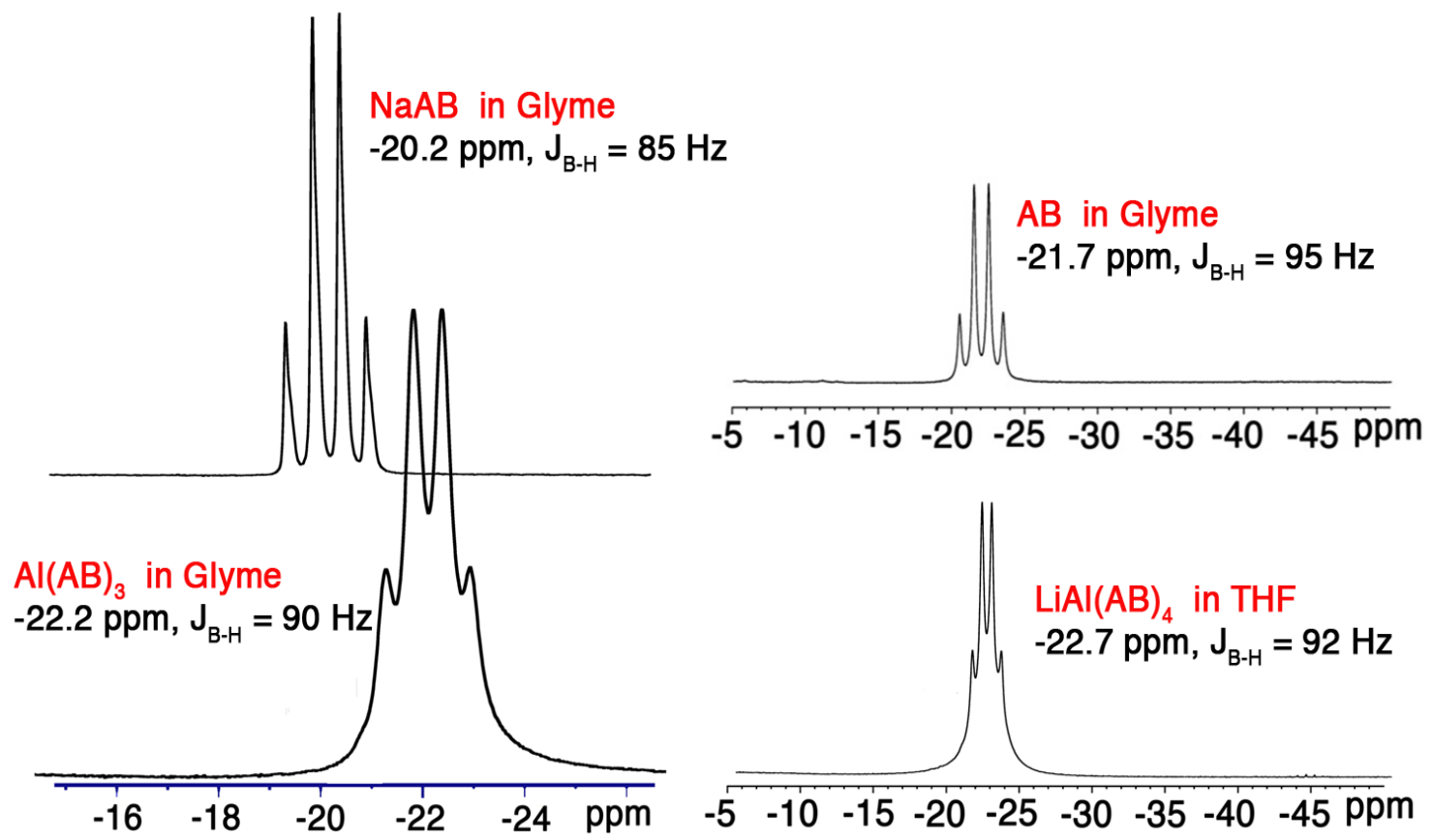

Figure 7 - NMR charecterization of Al-AB complexes.

$\mathrm{NH}_{3} \cdot \mathrm{Al}\left(\mathrm{NH}_{2} \mathrm{BH}_{3}\right)_{3}$ adduct: The ammonia adduct of $\mathrm{Al}(\mathrm{AB})_{3}$ was synthesized by reacting $\mathrm{Al}(\mathrm{AB})_{3}$ with an excess of ammonia in THF and was isolated as an insoluble precipitate. The complex was characterized by solid-state ${ }^{11} B$ NMR and IR spectroscopy.

$$
\mathrm{Al}\left(\mathrm{NH}_{2} \mathrm{BH}_{3}\right)_{3}+\mathrm{NH}_{3} \text { (excess) } \rightarrow \mathrm{NH}_{3} \cdot \mathrm{Al}\left(\mathrm{NH}_{2} \mathrm{BH}_{3}\right)_{3}
$$


Both $\mathrm{Al}(\mathrm{AB})_{3}$ and $\mathrm{LiAl}(\mathrm{AB})_{4}$ are colorless solids. $\mathrm{LiAl}(\mathrm{AB})_{4}$ is thermally more stable than $\mathrm{Al}(\mathrm{AB})_{3}$. Ammonia adduct of $\mathrm{Al}(\mathrm{AB})_{3}$ is a colorless polymeric compound insoluble in common organic solvents. A powder $\mathrm{X}$-ray diffraction study (figure 8) showed that the ammonia adduct is structurally similar to the parent $\mathrm{Al}\left(\mathrm{NH}_{2} \mathrm{BH}_{3}\right)_{3}$ complex.

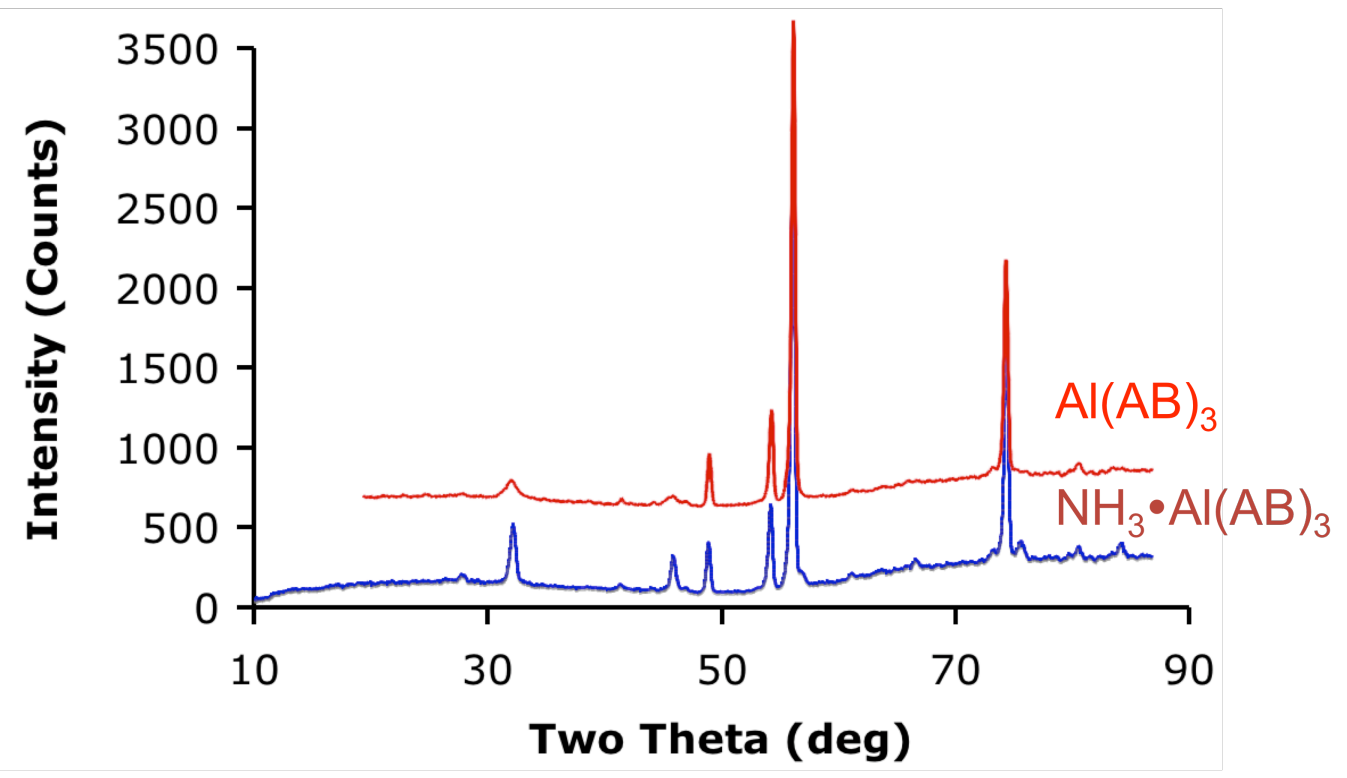

Figure 8 - Powder x-ray diffraction pattern of $\mathrm{Al}(\mathrm{AB})_{3}$ and its ammonium adduct.

\subsection{Thermal Dehydrogenation Studies on AI-AB Complexes}

TGA-MS analysis of Al-AB complexes performed at Los Alamos National Laboratory show that $\mathrm{Al}(\mathrm{AB})_{3}$ releases hydrogen at $60^{\circ} \mathrm{C}$ analogous to other $\mathrm{MAB}$ $(\mathrm{M}=\mathrm{Li}, \mathrm{Na})$ complexes (figure 9). The $\mathrm{LiAl}(\mathrm{AB})_{4}$ complex starts releasing hydrogen at $80^{\circ} \mathrm{C}$ (figure $9 \mathrm{C}$ ) and peaks at around $170^{\circ} \mathrm{C}$. The ammonia adduct $\mathrm{NH}_{3}{ }^{\circ} \mathrm{Al}(\mathrm{AB})_{3}$ generates hydrogen at $100^{\circ} \mathrm{C}$ but also releases ammonia at $100^{\circ} \mathrm{C}$ (figure 9B).

A differential scanning calorimetric analysis on $\mathrm{Al}(\mathrm{AB})_{3}$ indicates that the hydrogen release process is exothermic and therefore will require an off-board regeneration process (figure 9D). 


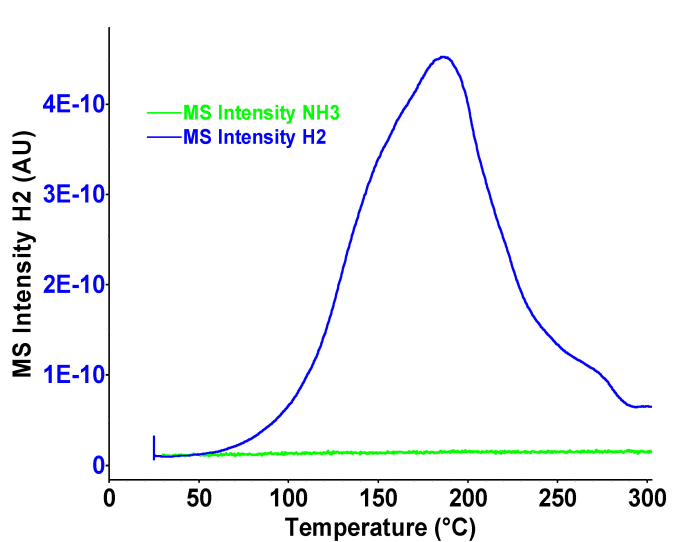

(A)

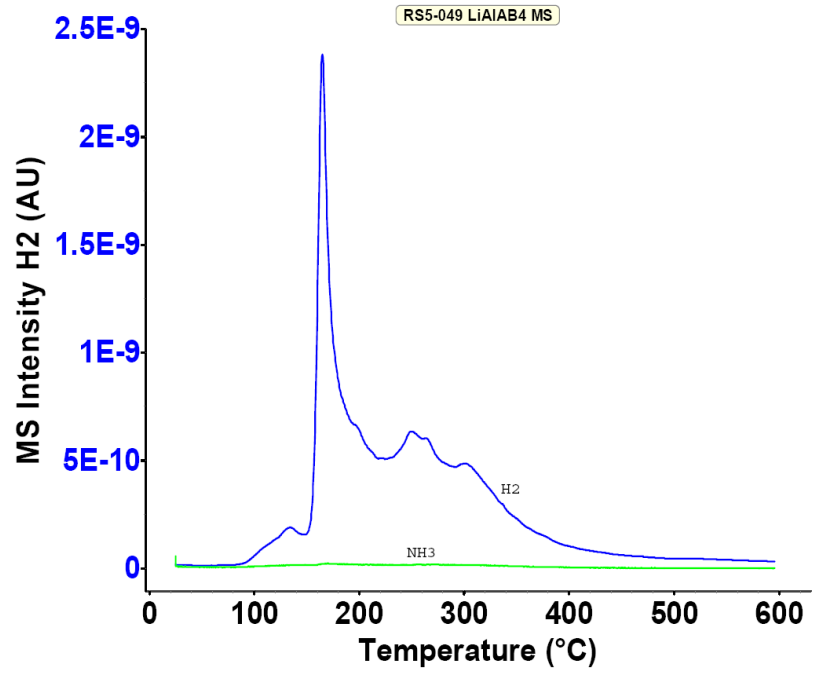

(C)

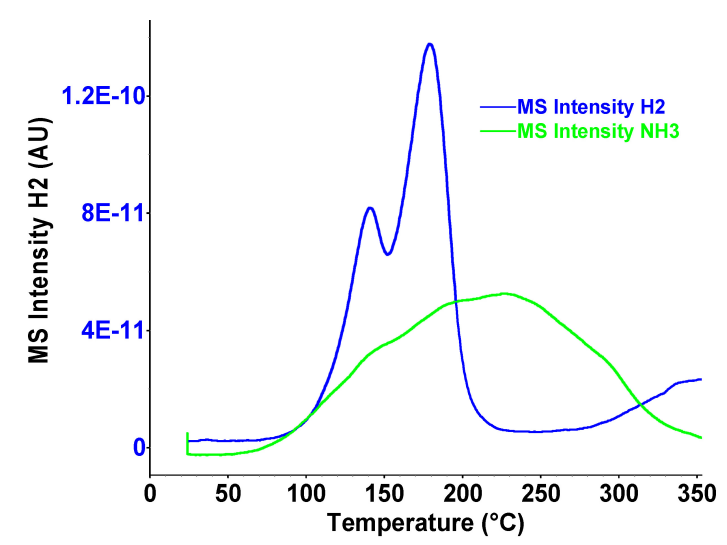

(B)

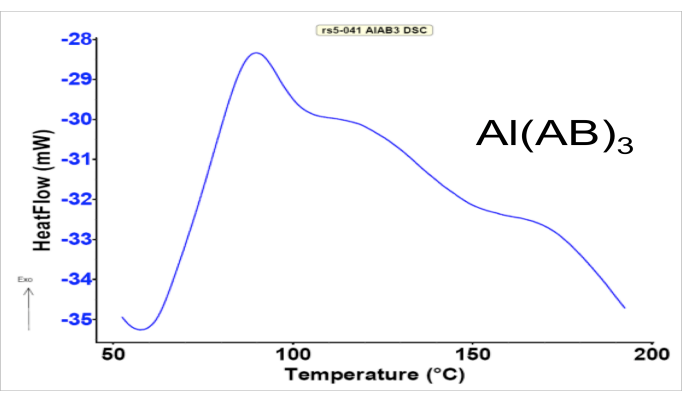

(D)

Figure 9 - TGA-MS and DSC of Al-AB complexes; $(A) A I(A B)_{3} ;(B)$ Ammonium adduct of $\mathrm{Al}(\mathrm{AB})_{3}$; (C) $\mathrm{LiAl}(\mathrm{AB})_{4} ;(\mathrm{D}) \mathrm{DSC}$ of $\mathrm{Al}(\mathrm{AB})_{3}$

\section{Thermal dehydrogenation of AI-AB complexes}

Hydrogen release experiments on $\mathrm{Al}(\mathrm{AB})_{3}$ and $\mathrm{LiAl}(\mathrm{AB})_{4}$ complexes were carried out at various temperatures by heating the complexes up to $190^{\circ} \mathrm{C}$ in the presence and absence of solvent or a catalyst. A plot of moles of hydrogen released vs.

temperature is shown in figure 11 . In the case of $\mathrm{Al}(\mathrm{AB})_{3}$ complex, approximately 4.1 moles of hydrogen is released at $190{ }^{\circ} \mathrm{C}$, which corresponds to about $6 \mathrm{wt} \%$ hydrogen based on material wt $\%$. The $\mathrm{LiAl}(\mathrm{AB})_{4}$ complex under similar experimental conditions released approximately 5.2 moles of hydrogen which corresponds to around $7 \mathrm{wt} \%$ hydrogen based on material wt\%. It has been shown that in the presence of an ionic liquid, the ammonia borane molecule releases hydrogen at lower temperatures. [19] We expected similar behavior for Al-AB complexes. Thus, 
in the presence of a ionic liquid 1-butyl-3-metylimidazolium tetrafluoroborate, the Al$A B$ complexes release $25-30 \%$ more hydrogen with virtually no induction period (figure $11 \mathrm{C}$ and $11 \mathrm{E}$ ). In both cases the hydrogen is released in a stepwise manner.

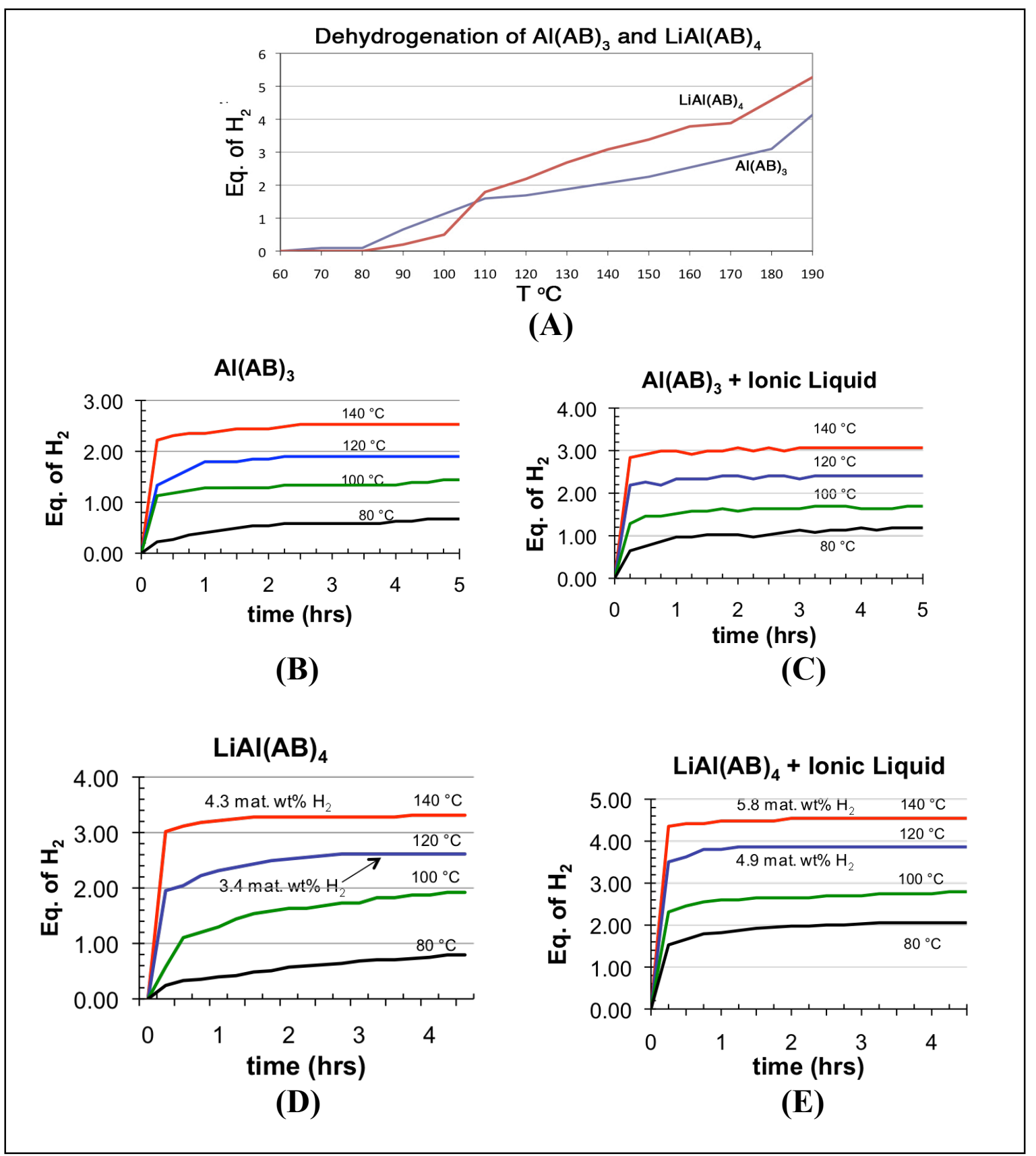

Figure 11 - Dehydrogenation of Al-AB complexes at various temperatures; $(A)$ Dehydrogenation of $\mathrm{Al}(\mathrm{AB})_{3}$ and $\mathrm{LiAl}(\mathrm{AB})_{4}$ at $190^{\circ} \mathrm{C}$; $(\mathrm{B}) \mathrm{Al}(\mathrm{AB})_{3} ;(\mathrm{C}) \mathrm{Al}(\mathrm{AB})_{3}$ in presence of ionic liquid, 1-butyl-3-methylimidazolium tetrafluoroborate; (D) $\operatorname{LiAl}(A B)_{4}$; (E) $\mathrm{LiAl}(\mathrm{AB})_{4}$ in the presence of ionic liquid, 1-butyl-3-methylimidazolium tetrafluoroborate. 


\subsection{Solution and solid phase NMR studies of dehydrogenation of $\mathrm{Al}(\mathrm{AB})_{3}$ and $\operatorname{LiAl}(\mathrm{AB})_{4}$ complexes.}

To understand the dehydrogenation pathway of Al-AB complexes, the products were analyzed by solution phase and solid phase ${ }^{11} B$ NMR. The solution phase NMR study was done by heating the respective glyme soltutions of $\mathrm{Al}(\mathrm{AB})_{3}$ and $\mathrm{LiAl}(\mathrm{AB})_{4}$ at $80^{\circ} \mathrm{C}$ and recording the ${ }^{11} \mathrm{~B}$ NMR spectrum of the mixture every 30 minutes. These results are presented in figure 12 for $\mathrm{Al}(\mathrm{AB})_{3}$ and figure 14 for $\mathrm{LiAl}(\mathrm{AB})_{4}$, respectively. In both cases at the onset of the dehydrogenation process, a large amount of precipitate is formed. In the case of $\mathrm{Al}(\mathrm{AB})_{3}$ the solution showed the formation of borazine at $31 \mathrm{ppm}, \mu$-aminodiborane at $-27 \mathrm{ppm}$, and ionic $\mathrm{BH}_{4}{ }^{-}$ species at $-41 \mathrm{ppm}$ (figure 12). The $\mathrm{LiAl}(\mathrm{AB})_{4}$ solution on the other hand did not show formation of $\mu$-aminodiborane which is present in the dehydrogenation of ammonia borane. The presence of $\mu$-aminodiborane in $\mathrm{Al}(\mathrm{AB})_{3}$ dehydrogenation process indicates that the thermally unstable $\mathrm{Al}(\mathrm{AB})_{3}$ complex releases $A B$ at the onset of the dehydrogenation process and forms a insoluble polymeric $\mathrm{Al}-\mathrm{AB}$ complex. The $A B$ released then follows ammonia borane dehydrogenation pathway. ${ }^{20}$ Due to formation of large amount of insoluble precipitate during dehydrogenation in solution, we carried out solid state NMR studies on the AI-AB dehydrogenated products. Both $\mathrm{Al}(\mathrm{AB})_{3}$ and $\mathrm{LiAl}(\mathrm{AB})_{4}$ were thermally decomposed at $120^{\circ} \mathrm{C}$ for $4 \mathrm{~h}$ and the materials were analyzed using solid phase ${ }^{11} \mathrm{~B} N \mathrm{NM}$ at $96 \mathrm{MHz}$. Solid NMR experiments were done using cross polarization (CPMAS) and magic angle spinning (MAS) methods in an attempt to observe the $\mathrm{B}-\mathrm{H}$ coupling peaks. However we could not quantify $\mathrm{B}-\mathrm{H}$ coupling constants due to broad line width and presence of boron background in the spectrum [figure 13 for $\mathrm{Al}(\mathrm{AB})_{3}$ and figure 15 for $\left.\mathrm{LiAl}(\mathrm{AB})_{4}\right]$. Dehydrogeantion products from both complexes showed strong peaks for $\mathrm{BH}_{4}{ }^{-}$anionic species at -39 and $-41 \mathrm{ppm}$.

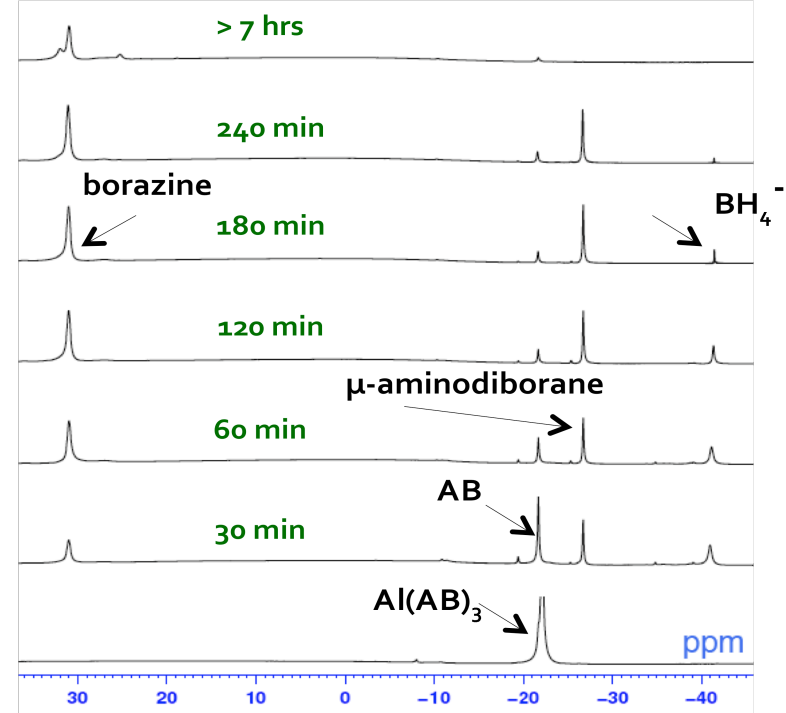

Figure 12. Solution ${ }^{11} \mathrm{~B}$ NMR $(160 \mathrm{MHz})$ of thermolysis products of $\mathrm{Al}(\mathrm{AB}){ }_{3}$ at $80{ }^{\circ} \mathrm{C}$ in glyme. 


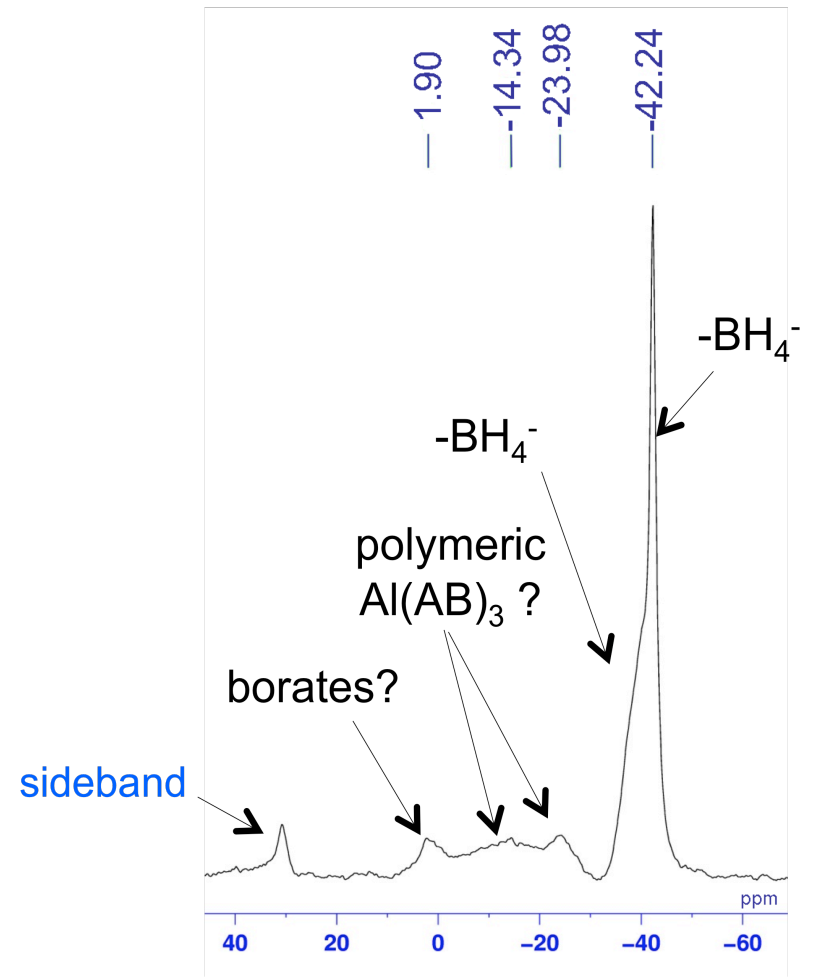

Figure 13. Solid state CPMAS ${ }^{11} \mathrm{~B}$ NMR $(96 \mathrm{MHz})$ of thermolysis products of $\mathrm{Al}(\mathrm{AB})_{3}$ after $4 \mathrm{~h}$ at $120^{\circ} \mathrm{C}$.

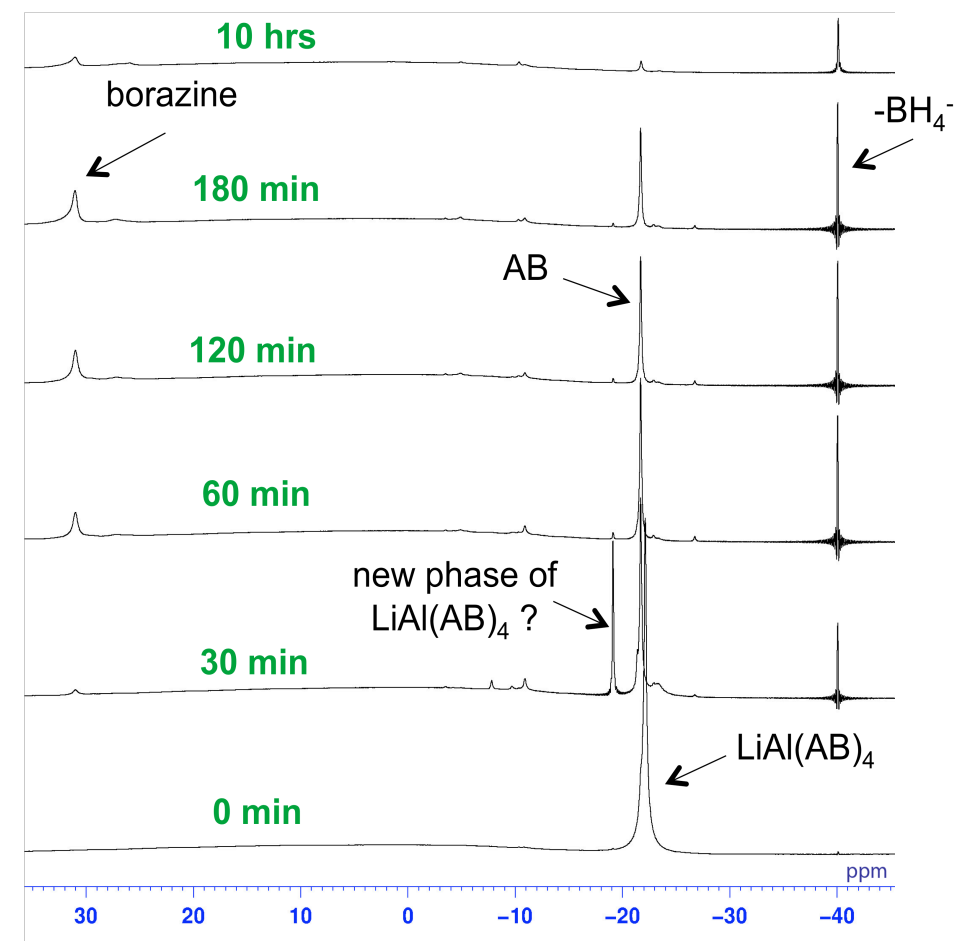

Figure 14. Solution ${ }^{11} \mathrm{~B}$ NMR $(160 \mathrm{MHz})$ of thermolysis products of $\mathrm{LiAl}(\mathrm{AB})_{4}$ at $80{ }^{\circ} \mathrm{C}$ in glyme. 


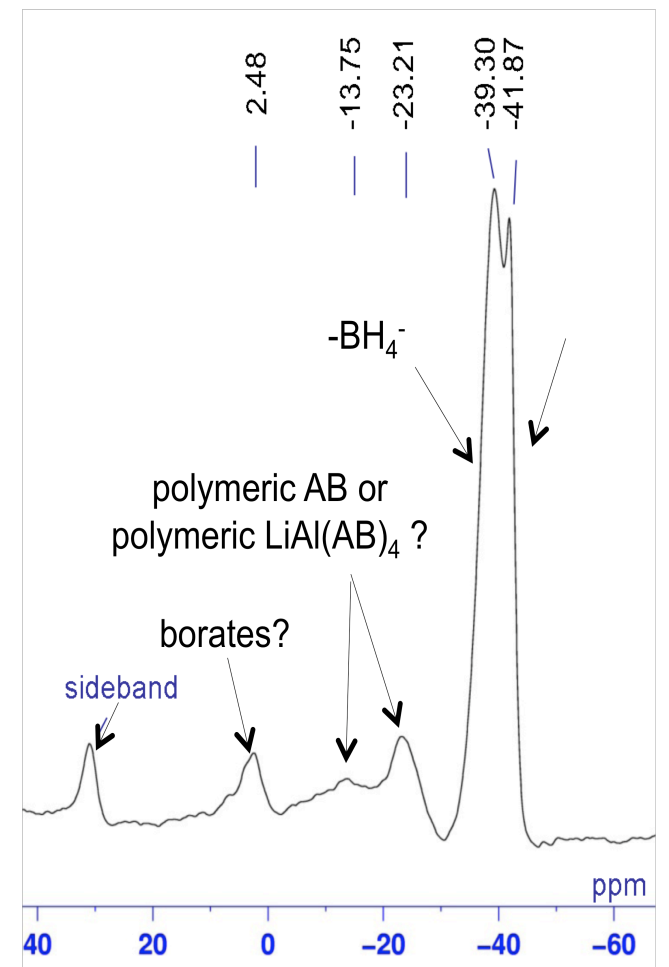

Figure 15. Solid state CPMAS ${ }^{11} \mathrm{~B}$ NMR $(96 \mathrm{MHz})$ of thermolysis products of $\mathrm{LiAl}(\mathrm{AB})_{4}$ after $4 \mathrm{~h}$ at $120^{\circ} \mathrm{C}$.

\section{Conclusions}

Aluminum ammonia-borane complexes are viable candidates for chemical hydrogen storage. They can be easily synthesized from ammonia borane precursors and they generate hydrogen at lower temperature than $\mathrm{AB}$ alone. Thermal decomposition of Al$A B$ complexes releases hydrogen in a stepwise manner and peak around $190^{\circ} \mathrm{C}$. The $\mathrm{Al}(\mathrm{AB})_{3}$ complex releases approximately 4.1 equivalents $(6 \mathrm{wt} \%)$ of hydrogen at $190{ }^{\circ} \mathrm{C}$ and $\mathrm{LiAl}(\mathrm{AB})_{4}$ releases approximately 5.2 equivalents $(7 \mathrm{wt} \%)$ under same conditions. The presence of an ionic liquid, 1-butyl-3-methylimidazolium tetrafluoroborate enhances the hydrogen release performance of Al-AB complexes by almost $25-30 \%$.

\section{Key Results}

- Synthesized various $\mathrm{Al}-\mathrm{AB}$ complexes. These include $\mathrm{Al}(\mathrm{AB})_{3}, \mathrm{LiAl}(\mathrm{AB})_{4}$ and their ammonia adduct of $\mathrm{Al}(\mathrm{AB})_{3}$.

- $\mathrm{Al}(\mathrm{AB})_{3}$ complex releases hydrogen at $60{ }^{\circ} \mathrm{C}$ while the $\mathrm{LiAl}\left(\mathrm{NH}_{2} \mathrm{BH}_{3}\right)_{4}$ complex starts releasing hydrogen at $80^{\circ} \mathrm{C}$.

- The ammonia adduct of $\mathrm{Al}(\mathrm{AB})_{3}$ generates hydrogen at $100{ }^{\circ} \mathrm{C}$, but also releases a significant amount of ammonia. 
- Presence of an ionic liquid enhances hydrogen release perfomance of Al-AB complexes.

- Differential scanning calorimetric studies on $\mathrm{Al}\left(\mathrm{NH}_{2} \mathrm{BH}_{3}\right)_{3}$ indicate that the hydrogen release from this complex is exothermic and will require off-board regeneration.

\section{Publications/Presentations}

1. Alexander V. Safronov, Satish S. Jalisatgi, Han Baek Lee, M.Frederick Hawthorne, 'Chemical Hydrogen Storage using Polynuclear Borane Anions", Int. J. Hydrogen Energy, In Press; DOI: 10.1016/j.ijhydene.2010.08.120

2. Poster presentation at DOE annual merit review, Washington DC, May 2009.

3. Poster presentation at DOE annual merit review, Washington DC, June 2010.

\section{Acronyms}

$\begin{array}{ll}\mathrm{AB} & \text { Ammonia Borane } \\ \mathrm{Al}(\mathrm{AB})_{3} & \mathrm{Al}\left(\mathrm{NH}_{2} \mathrm{BH}_{3}\right)_{3} \\ \mathrm{LiAl}(\mathrm{AB})_{4} & \mathrm{LiAl}\left(\mathrm{NH}_{2} \mathrm{BH}_{3}\right)_{4} \\ \text { TGA-MS } & \text { Thermogravimetric analysis - mass spectra } \\ \text { DSC } & \text { Differential scanning colorometry }\end{array}$




\section{REFERENCES}

1. For example (a) C. Liu, F. Li, L.-P. Ma, H. M. Cheng, Advanced Materials for Energy Storage, Adv. Mater. 22 (2010) E28. (b) G. L. Guizzi and M. Manno and M. De Falco, Hybrid fuel cell-based energy system with metal hydride hydrogen storage for small mobile applications, Int. J. Hydrogen Energy. 34 (2009) 3112. (c) J. Yang, A. Sudik, C. Wolvertonb, D. J. Siegelw, High capacity hydrogen storage materials: attributes for automotive applications and techniques for materials discovery, Chem. Soc. Rev. 39 (2010) 656. (d) L. Schlapbach, A. Zuttel, Hydrogen-storage materials for mobile applications, Nature. 414 (2001) 353.

2. (a) E. Y. Marrero-Alfonso, A. M. Beaird, T. A. Davis, M. A. Matthews, Hydrogen Generation from Chemical Hydrides, Ind. Eng. Chem. Res. 48 (2009) 3703. (b) T. K. Mandal, D. H. Gregory, Hydrogen storage materials: present scenarios and future directions, Annu. Rep. Prog. Chem., Sect. A. 105 (2009) 21. (c) B. Sakintuna, F. Lamari-Darkrimb, M. Hirscher, Metal hydride materials for solid hydrogen storage: A review, Int. J. Hydrogen Energy. 32 (2007) 1121. (d) W. Grochala, P. P. Edwards, Thermal Decomposition of the Non-Interstitial Hydrides for the Storage and Production of Hydrogen, Chem. Rev. 104 (2004) 1283.

3. Y. Kojima, T. Haga, Recycling process of sodium metaborate to sodium borohydride, Int. J. Hydrogen Energ. 28 (2003), 989.

4. (a) I. B. Sivaev, V. I. Bregadze, S. Sjoberg, Chemistry of closo-dodecaborate anion $\left[\mathrm{B}_{12} \mathrm{H}_{12}\right]^{2-}$ : a review, Collect. Czech. Chem. Commun. 67 (2002) 679. (b) R. E. Williams, The polyborane, carborane, carbocation continuum: architectural patterns, Chem. Rev. 92 (1992) 177. (c) B. Štíbr, Carboranes other than $\mathrm{C}_{2} \mathrm{~B}_{10} \mathrm{H}_{12}$, Chem. Rev. 92 (1992) 225. (d) W. N. Lipscomb, A. R. Pitochelli, M. F. Hawthorne, Reactions of bis-acetonitrile decaborane with amines, J. Am. Chem. Soc. 81 (1959) 5833. (e) A. R. Pitochelli, M. F. Hawthorne, Isolation of the icosahedral $\mathrm{B}_{12} \mathrm{H}_{12}{ }^{2-}$ ion, J. Am. Chem. Soc. 82 (1960) 3228.

5. (a) M. F. Hawthorne, New horizons for therapy based on the boron neutron capture reaction, Mol. Med. Today. 4 (1998) 174. (b) T. Li, S. S. Jalisatgi, M. J. Bayer, A. Maderna, S. I. Khan, M. F. Hawthorne, Organic Syntheses on an Icosahedral Borane Surface: Closomer Structures with Twelvefold Functionality, J. Am. Chem. Soc. 127 (2005) 17832. (c) V.I. Bregadze, I.B. Sivaev, S.A. Glazun, Polyhedral boron compounds as potential diagnostic and therapeutic antitumor agents, Anti-Cancer Agents in Medicinal Chemistry. 6 (2006) 75. (d) A.V. Orlova, L. O. Kononov, Synthesis of conjugates of polyhedral boron compounds with carbohydrates, Russian Chemical Reviews. 78 (2009) 629. (e) I. B. Sivaev, V. I. Bregadze, Polyhedral boranes for medical applications: current status and perspectives, Eur. J. Inorg. Chem. (2009) 1433. (f) J. Plešek, Potential 
applications of the boron cluster compounds, Chem. Rev. 92 (1992) 269.

6. M. T Kelly, Y. Wu, J. C. Brady, M. F. Hawthorne, Fuel blends for hydrogen generators, U.S. Patent Application No. 20050132640, (2005).

7. (a) A. H. Soloway, R. L. Wright, and J. R. Messer, Evaluation of boron compounds for use in neutron-capture therapy of brain tumors. I. Animal investigations, J. Pharmacol. Exp. Ther. 134 (1961) 117. (b) A. H. Soloway, H. Hatanaka, and M. A. Davis, Penetration of brain and brain tumor. VII. Tumorbinding sulfhydryl boron compounds, J. Med. Chem., 10 (1967) 714.

8. W. H. Sweet, A. N. Soloway, and R. L. Wright, Evaluation of boron compounds for use in neutron capture therapy of brain tumors. II. Studies in man, J. Pharmacol. Expil. Therap. 137 (1962) 263.

9. M. F. Hawthorne, R. L. Pilling, Bis(triethylammonium) decahydrodecaborate(2-), Inorg. Synth.10 (1967) 16.

10. H. C. Miller, E. L. Muetterties, Borane anions, Inorg. Synth. 10 (1967) 81.

11. M. J. Bayer, M. F. Hawthorne, An Improved Method for the Synthesis of [closo$\left.\mathrm{B}_{12}(\mathrm{OH})_{12}\right]^{-2}$, Inorg. Chem. 43 (2004) 2018.

12. W. H. Knoth, H. C. Miller, J. C. Sauer, J. H. Balthis, Y. T. Chia and E. L. Muetterties, Chemistry of boranes. IX. Halogenation of $\mathrm{B}_{10} \mathrm{H}_{10}{ }^{2-}$ and $\mathrm{B}_{12} \mathrm{H}_{12}{ }^{2-}$, Inorg. Chem. 3 (1964) 159.

13. (a) H.I. Schlesinger, H.C. Brown, A.E. Finholt, J.R. Gilbreath, H.R. Hoekstra and E.K. Hyde, Sodium borohydride, its hydrolysis and its use as a reducing agent and in the generation of hydrogen, J. Am. Chem. Soc. 75 (1953) 215. (b) P. C. Maybury, R. W. Mitchell, M. F. Hawthorne, Hydrogen adducts of cobalt and nickel boride, Chem. Comm. (1974) 534.

14. (a) V. D. Aftandilian, H. C. Miller, G. W. Parshall, E. L. Muetterties, Chemistry of boranes. V. First example of a $\mathrm{B} 11$ hydride, the $\mathrm{B}_{11} \mathrm{H}_{14}{ }^{-}$anion, Inorganic Chemistry 1 (1962) 734. (b) H. C. Miller, N. E. Miller, E. L. Muetterties, Chemistry of boranes. XX. Syntheses of polyhedral boranes, Inorg. Chem. 3 (1964) 1456.

15. V. Geis, K. Guttsche, C. Knapp, H. Scherer, R. Uzun, Synthesis and characterization of synthetically useful salts of the weakly-coordinating dianion $\left[\mathrm{B}_{12} \mathrm{Cl}_{12}\right]^{2-}$, Dalton Trans. (2009) 2687.

16. (a) M. Zahmakiran, S. Özkar, Water dispersible acetate stabilized ruthenium(0) nanoclusters as catalyst for hydrogen generation from the hydrolysis of sodium borohyride, J. Mol. Catal. A: Chemical. 258 (2006) 95. (b) Ö. Metin, S. Özkar, Hydrogen generation from the hydrolysis of sodium borohydride by using water 
dispersible, hydrogenphosphate-stabilized nickel(0) nanoclusters as catalyst, Int. J. Hydrogen Energy. 32 (2007) 1707. (c) J. C. Ingersoll, N. Mania, J.C.

Thenmozhiyal, A. Muthaiah, Catalytic hydrolysis of sodium borohydride by a novel nickel-cobalt-boride catalyst, Journal of Power Sources. 173 (2007) 450.

17. (a) F. H. Stephens, V. Pons, R. T. Baker, Ammonia borane: the hydrogen source par excellence?, Dalton Trans. 25 (2007) 2613.; (b) S. i. Orimo, Y. Nakamori, J. R. Eliseo, A. Züttel, C. M. Jensen, Complex hydrides for hydrogen storage, Chem. Rev. 107 (2007), 4111.; (b) C. W. Hamilton, R. T. Baker, A. Staubitz, I. Manners B-n compounds for chemical hydrogen storage, Chem. Soc. Rev. 38 (2009), 279.; (c)

18. (a) Z. Xong, C.K. Yong, G. Wu, P. Chen, W. Shaw, A. Karmarker, T. Autrey, M. O. Jones, S. R. Johnson, P. P. Edwards, W. I. F. David, , Nat. Mater. 7 (2008) 138.; (b) X. Kang, Z. Fang, L. Kong, H. Cheng, X. Yao, G. Lu, P. Wang, , Adv. Mater. 20 (2008) 2756.; (c) Z. Xiong, G. Wu, Y. S. Chua, J. Hu, T. He, W. Xu, P. Chen, , Energy Environ. Sci. 1 (2008) 360.; (d) A. T. Luedtke, T. Autrey, Hydrogen release studies of Alkali Metal Amidoboranes, Inorg. Chem. 49 (2010) 3905.

19. (a) Bluhm, M. E.; Bradley, M. G.; Butterick III, R.; Kusari, U.; Sneddon, L. G. Amineborane-Based Chemical Hydrogen Storage: Enhanced Ammonia Borane Dehydrogenation in Ionic Liquids, J. Am. Chem. Soc., , 128 (2006) 7748; (b) Himmelberger, D. W.; Alden, L. R.; Bluhm, M. E.; Sneddon, L. G. "Ammonia Borane Hydrogen Release in Ionic Liquids”, Inorg. Chem. 48 (2009) 9883.

20. (a) Stowe, A. C.; Shaw, W. J.; Linehan, J. C.; Schmid, B.; Autrey, T. "In situ solid state ${ }^{11} \mathrm{~B}$ MAS-NMR studies of the thermal decomposition of ammonia borane: mechanistic studies of the hydrogen release pathways from a solid state hydrogen storage material", Phys. Chem. Chem. Phys. 9 (2007) 1831; (b) Shaw, W.J.; Linehan, J. C.; Szymczak, N. K.; Heldebrant, D. J.; Yonker C.; Camaioni, D. M.; Baker, R. T.; Autrey, T. "In Situ Nultinuclear NMR Spectroscopic Studies of the Thermal Decomposition of Ammonia Borane in Solution", Angew. Chem. Int. Ed. 47 (2008) 7493. 